\title{
Electricity generation through degradation of organic matters in medicinal herbs wastewater using bio-electro-Fenton system
}

\author{
Noushin Birjandi ${ }^{\mathrm{a}}$, Habibollah Younesi ${ }^{\mathrm{b}}$, Ali Asghar Ghoreyshi ${ }^{\mathrm{c}}$, Mostafa Rahimnejad $^{\mathrm{c}}$ \\ ${ }^{a}$ Department of Environmental Science, Faculty of Agriculture and Natural Resources, \\ Lorestan University, Khorramabad, Iran \\ ${ }^{\mathrm{b}}$ Department of Environmental Science, Faculty of Natural Resources, Tarbiat Modares \\ University, Imam Reza Street, Noor, Iran, P.O. Box: 46414-356 \\ ${ }^{\mathrm{c}}$ Biotechnology Research Lab, Faculty of Chemical Engineering, Noshirvani University, \\ Babol, Iran
}

\begin{abstract}
In the present study, the potential application of the bio-electro-Fenton (BEF) process for the treatment of medicinal herbs wastewater in a mediator-less microbial fuel cell (MFC) system is investigated. This process is operated in a dual-chamber MFC with anaerobic seed sludge as biocatalyst in an anode chamber under conditions of neutral $\mathrm{pH}$, an aerobic cathode chamber equipped with a Fe@ $\mathrm{Fe}_{2} \mathrm{O}_{3} /$ graphite composite cathode and a Nafion membrane as a separator. The performance of the MFC is determined in three different mixed liquor suspended solids (MLSS) loadings, Nafions $(112,115)$ and a salt bridge in an air-cathode BEF process, in terms of power generation, chemical oxygen demand (COD) removal efficiency, columbic and energy efficiencies. Under optimal conditions, the batch experiment results show that the cathode chamber of the BEF reactor, equipped with Nafion 112 and inoculated with seed sludge at $3000 \mathrm{mg} \mathrm{L}^{-1}$ MLSS concentration, produces the maximum power density of $49.76 \mathrm{~mW} \mathrm{~m}^{-2}, 0.56 \mathrm{mg} \mathrm{L}^{-1}$ and $29 \mathrm{~mol} \mathrm{~L}^{-1}$ of $\mathrm{H}_{2} \mathrm{O}_{2}$ and $\mathrm{Fe}^{2+}$, respectively. Under these conditions, the MFC achieves COD removal $78.05 \%$ in the anaerobic anode chamber and $84.02 \%$ as a result of aerobic processes from the air-cathode BEF chamber, whilst the maximum voltage $\epsilon_{\mathrm{cb}}$ and $\epsilon_{\mathrm{E}}$ values are $600 \mathrm{mV}, 4.09 \%$ and $1.37 \%$, respectively.
\end{abstract}

\footnotetext{
*Corresponding Author: Email: hunesi@modares.ac.ir, hunesi@yahoo.com Tel: +98 (11) 44553101-3, Fax: +98 (11) 44553499
} 
Keywords: Bio-electro-Fenton; mediator-less MFC; energy recovery; medicinal herbs wastewater

\section{Introduction}

To remove inorganic or organic pollutants from wastewaters, many treatment techniques have been proposed, however, most processes involve high operational costs or large amounts of land (Min et al., 2005). One useful approach creating bioenergy from organic matter involves employing microbial fuel cell (MFC), a novel technology for wastewater treatment that generates electricity directly from organic compounds (Min et al., 2005; Sun et al., 2009; Xu et al., 2011). The amount of power output is dependent on the source of the organic matter and the type of reactor (Min et al., 2005). In recent years, due to this property of recovering electricity from wastewaters and waste biomass sources, MFCs have been widely investigated (Fan et al., 2012; Zhu \& Logan, 2013). In MFCs, the organic materials are oxidized by microorganisms and produce electrons and protons in the anode chamber under anaerobic conditions. Therefore, generated bioelectrons are transferred across a conductive material containing a resistor to the cathode chamber where they are consumed to reduce oxygen or other chemicals as electron acceptors (Lu et al., 2009; Rabaey et al., 2003). In addition, the produced protons migrate simultaneously through a membrane from the anode into the cathode (Zhuang et al., 2010a). In order to provide such microbial diversity, various types of sludge, aquatic sediments and wastewaters are usually utilized as anode inocula (Mashkour \& Rahimnejad, 2015; Sun et al., 2009). The MFCs are environmentally friendly energy systems with no pollutants such as metal ions, toxic gases or organic wastes being generated during their operation (Fernández de Dios et al., 2013), however, they are inefficient for industrial wastewater treatment, particularly, for wastewater containing biorefractory pollutants. 
As a result, MFCs have been coupled with other treatment processes such as Fenton reaction, which is one of the advanced oxidation processes $\left(\mathrm{AOP}_{\mathrm{s}}\right)($ Cheng et al., 2010; $\mathrm{Xu}$ et al., 2011; Yuan et al., 2010). Zhu and Ni (Zhu \& Ni, 2009b) have suggested the concept of using electrons produced in a metabolic activity to drive electro-Fenton reactions for pollutant degradation in the MFC cathode. Furthermore, Luo et al. (Luo et al., 2011) and Xu et al. (Xu et al., 2013) studied the simultaneous degradation of pollutants in both the anode and cathode chambers. The sequence of the bio-electrochemical reactions in the anode chamber lead to the multiple reactions like bio-chemical, physical, physicochemical, electrochemical and oxidation as a result of substrate metabolic activity (Pham et al., 2009; Venkata Mohan et al., 2008a). The possibility of integrating multiple processes in the anodic chamber has a positive influence on the overall wastewater treatment efficiency (Mohanakrishna et al., 2010). Feng et al (Feng et al., 2010a) reported the complete decolorization and mineralization of Orange II by Fenton process in an MFC equipped with a carbon nanotube with $(\mathrm{CNT}) / \gamma-\mathrm{FeOOH}$ composite cathode. It has been demonstrated that the combination of MFC and electroFenton process, known as bio-electro-Fenton (BEF) system, can efficiently decompose biorefractory pollutants (Feng et al., 2010b; Zhu \& Ni, 2009a). Based on this fact, Wang et al (Wang et al., 2014) demonstrated that the BEF system makes it a potentially attractive method for the detoxification of As(III) from aqueous solution. In their experiments, the apparent oxidation current efficiency was calculated to be as high as $73.1 \%$. and the $\gamma-$ $\mathrm{FeOOH}$ dosage in the cathode was an important factor in determining the system performance. Zhuang et al. (Zhuang et al., 2010b) also developed an integrated system coupling an MFC with the cathodic electro-Fenton process. In this system, $\mathrm{H}_{2} \mathrm{O}_{2}$ can be generated in the cathode chamber via a two-electron reduction of oxygen, as shown in Eq (1). $\mathrm{O}_{2}+2 \mathrm{H}^{+}+2 \mathrm{e}^{-} \rightarrow \mathrm{H}_{2} \mathrm{O}_{2}$ 
The Fe-impregnated graphite plate and iron oxide are used as cathode or cathodic catalyst under an acidic condition and the oxidation process assumed to be described by the following equations:

$\mathrm{Fe}+2 \mathrm{H}^{+} \rightarrow \mathrm{Fe}^{2+}+\mathrm{H}_{2}$

$\mathrm{Fe}+\mathrm{O}_{2}+2 \mathrm{H}^{+} \rightarrow \mathrm{Fe}^{2+}+2 \mathrm{HO}^{\bullet}$

$\mathrm{Fe}_{2} \mathrm{O}_{3}+6 \mathrm{H}^{+} \rightarrow 2 \mathrm{Fe}^{3+}+2 \mathrm{H}_{2} \mathrm{O}$

Then, $\mathrm{H}_{2} \mathrm{O}_{2}$ reacts with $\mathrm{Fe}^{2+}$ and $\mathrm{Fe}^{3+}$ to produce hydroxyl $\left(\mathrm{HO}^{\circ}\right)$ and hydroperoxy $\left(\mathrm{HO}_{2}{ }^{\circ}\right)$ radicals which can react with organic pollutants (Feng et al., 2010b; Zhuang et al., 2010a), as seen in Eqs. (5) and (6):

$\mathrm{H}_{2} \mathrm{O}_{2}+\mathrm{Fe}^{2+} \rightarrow \mathrm{Fe}^{3+}+\mathrm{OH}^{\bullet}+\mathrm{OH}^{-}$

$\mathrm{Fe}^{3+}+\mathrm{H}_{2} \mathrm{O}_{2} \rightarrow \mathrm{Fe}^{2+}+\mathrm{HO}_{2}^{\cdot}+\mathrm{H}^{+}$

Instead of directly using $\mathrm{Fe}^{2+}$ as the iron source, we used a self-designed electrode such as $\mathrm{Fe} @ \mathrm{Fe}_{2} \mathrm{O}_{3}$ /graphite composite cathode for the electro-Fenton process, as recommended by previous researchers (Zhuang et al., 2010b). The ability to self-regulate the supply of a constant amount of iron ions all along the reaction time and also the easy recycling of the iron catalyst after treatment are the advantages of using in situ iron sources in the electro-Fenton process (Ai et al., 2007b; Li et al., 2009; Sánchez-Sánchez et al., 2007). A novel environmental biotechnological process, such as MFC combined with chemical methods, was increasingly drawing the interest of researchers engaging in work in this area of biological wastewater treatment. In most applications, despite the economic and technical advantages and treatment of high strength organic wastewater using this method, the effect of different operational and environmental factors has not yet been clearly described. Therefore, the main objective of this study was to demonstrate the feasibility of bioelectro-Fenton system in a mediator-less MFC uses a $\mathrm{Fe} @ \mathrm{Fe}_{2} \mathrm{O}_{3} /$ graphite plate composite cathode for the simultaneous treatment of medicinal herbs wastewater at the anode and the cathode degradation of organic 
materials by Fenton reaction. The laboratory experiments were carried out in a dual-chamber to optimize the anode and cathode condition for improving the performance of the BEF reactor throughout the wastewater treatment.

\section{Experimental procedure}

\subsection{Wastewater composition}

In this study, medicinal herbs wastewater was obtained from Soha Jissa factory, a manufacturer for medicinal herbs, located in a Salmanshahr city in the north of Iran. This wastewater contains unique pollutants such as oil, alcohol, propylene glycol and cellulose, and requires on-site treatment to avoid harmful contamination of water resources and natural water bodies. The characteristics of medicinal herbs wastewater for the examination of water and wastewater (APHA, 1998) were measured according to standard methods, as listed in Table 1. The values are averages of three determinations, with standard deviations lower than $5 \%$. The $\mathrm{pH}$ of medicinal herbs wastewater was found in a range from 11.5 to 12.3 , giving an average value of $12.15 \pm 0.61$, indicating strong alkaline nature where caustic alkali are used in a large quantity. Soluble chemical oxygen demand (COD) and biochemical oxygen demand (BOD) of wastewater were found to be in the range of 4398 to $4476 \mathrm{mg} \mathrm{L}^{-1}$ and 2207-2313 $\mathrm{mg} \mathrm{L}^{-1}$, giving an average value of $4425 \pm 221 \mathrm{mg} \mathrm{L}^{-1}$ and $2250 \pm 112 \mathrm{mg} \mathrm{L}^{-1}$, respectively. The medicinal herbs wastewater contains biodegradable constituents with a $\mathrm{BOD} / \mathrm{COD}$ ratio of 0.51 , indicating can be treatment by biological means. Total suspended solids (TSS) and volatile suspended solids (VSS) of wastewater were found to be in the range of $1383-1498 \mathrm{mg} \mathrm{L}^{-1}$ and $1145-1280 \mathrm{mg} \mathrm{L}^{-1}$, giving an average value of $1423 \pm 71 \mathrm{mg} \mathrm{L}^{-1}$ and $1211 \pm 61 \mathrm{mg} \mathrm{L}^{-1}$, respectively. The total suspended solids in this wastewater have a high volatile solid, indicating that this can be successfully digested under anaerobic conditions. However, after allowing sediment to settle out of suspension due to gravity, the medicinal 
herbs wastewater was used in the BEF system. The anaerobic sludge used as inoculums was collected from a reactor treating dairy wastewater from the Shir Khameh dairy industry of Noor, Mazandaran, Iran. The seed sludge was cultivated at $35^{\circ} \mathrm{C}$. The medicinal herbs wastewater and inocula were stored at $4{ }^{\circ} \mathrm{C}$ until use.

\subsection{Bio-electro-Fenton reactor configuration and operation}

All experiments were conducted using a BEF reactor operated in a batch mode at a controlled temperature of $30^{\circ} \mathrm{C}$ and ambient atmospheric pressure. The proposed $\mathrm{BEF}$ reactor was constructed in two rectangular chambers of the same size $(100 \mathrm{~mm} \times 100 \mathrm{~mm} \times 60 \mathrm{~mm})$, separated by a proton exchange membrane (PEM; Nafion, Sigma-Aldrich, USA). Nafion is the best known membrane as it can selectively transfer protons and is resistant in the transmission of oxygen from cathode to anode chamber. The pre-treatment steps for taking off any impurities consisted of boiling the Nafion for $1 \mathrm{~h}$ in $3 \% \mathrm{H}_{2} \mathrm{O}_{2}$ solution, then washing with deionized water and $0.5 \mathrm{M} \mathrm{H}_{2} \mathrm{SO}_{4}$ solution. Finally, the Nafion was washed again with deionized water. Each chamber (anode and cathode) was made of plexiglass and had a working volume of $450 \mathrm{~mL}$. Anode and cathode electrodes had the same dimensions of 45 $\mathrm{mm}$ of height, $25 \mathrm{~mm}$ length and $3 \mathrm{~mm}$ of thickness. The electrodes were graphite plates (Entegris, Inc. FCBLK-508305-00004, USA) installed in each chamber in parallel with a gap between them of approximately $7 \mathrm{~cm}$. The same electrodes were used in both anode and cathode chambers. Prior to use, the graphite plates were soaked in acetone for $15 \mathrm{~min}$ and boiled in $0.1 \mathrm{M} \mathrm{HCl}$ for $20 \mathrm{~min}$, then washed with distilled water to eliminate foreign compounds from the surface of the electrodes. The electrodes were connected with copper wire with $2 \mathrm{~mm}$ diameter and $50 \mathrm{~cm}$ length through an external resistance of $100 \Omega$ and an analog digital data logger. The electricity output was continuously recorded every $30 \mathrm{~min}$ for $50 \mathrm{~h}$. Polarization and power density curves as a function of current density were obtained by 
varying the external resistance from 100 to $100000 \Omega$ when maximum available voltage output was approached. The power densities were normalized to the projected surface area of the cathode $\left(11.25 \mathrm{~cm}^{2}\right)$. Then, the data logger provides power calculation by multiplication of voltage and current. The provisions were provided for online observation of the polarization curve showing the variation of power density and MFC voltage with respect to the current. The power, current and voltage were automatically recorded by the computer connected to the system (Birjandi et al., 2015).

The Fe@ $\mathrm{Fe}_{2} \mathrm{O}_{3}$ /graphite composite cathode was manufactured according to the procedures described elsewhere (Feng et al., 2010b; Zhuang et al., 2010b), serving as the iron source for the in situ electro-Fenton process in the cathode chamber. In a typical procedure, different amount of $\mathrm{FeCl}_{3}-6 \mathrm{H}_{2} \mathrm{O}(0.7,0.9$ and $1 \mathrm{~g})$ and $1.8 \mathrm{~g}$ of $\mathrm{NaBH}_{4}$ were dissolved in 100 and 40 $\mathrm{mL}$ distilled water, respectively, to form a clear ferric solution and $\mathrm{NaBH}_{4}$ solution. The graphite plate was ultrasonically treated in the ferric solution for $20 \mathrm{~min}$, and then $\mathrm{NaBH}_{4}$ solution was slowly added, leading to the reduction of ferric ions into metallic iron on the graphite. The composite electrode was ready for use after being rinsed with deionized water and dried in nitrogen flow. The schematic diagram with auxiliary equipments of the fabricated MFC cell in batch system is shown in Fig. 1. The anodic chamber was inoculated with the seed sludge (mixed microorganisms) and fed with 450 medicinal herbs wastewater as a fuel substrate containing (per liter of wastewater): yeast extract, $0.1 \mathrm{~g} ; \mathrm{KH}_{2} \mathrm{PO}_{4}, 0.53 \mathrm{~g}$; $\mathrm{Na}_{2} \mathrm{HPO}_{4}, 1.07 \mathrm{~g} ; \mathrm{NH}_{4} \mathrm{Cl}, 0.2 \mathrm{~g} ; \mathrm{KCl}, 0.13 \mathrm{~g} ; \mathrm{CaCl}_{2}, 0.02 ; \mathrm{NaHCO}_{3}, 0.073$; and trace mineral solution $0.1 \mathrm{~mL}$ (Daneshi et al., 2010). The content of the anodic chamber was mixed, using a magnetic stirrer to maintain homogeneous conditions with the $\mathrm{pH}$ of the wastewater adjusted to 7 to support the activity of microorganisms present in the seed sludge. Anode chamber was sparged with nitrogen gas to maintain anaerobic condition. The cathode chamber was filled with medicinal herbs wastewater and continuously bubbled with air at a rate of $300 \mathrm{~mL} \mathrm{~min}^{-1}$ 
to provide oxygen for the two-electron oxygen reduction reactions (ORR). Under this condition, the $\mathrm{pH}$ of the cathodic solution reached 3.0 by adding $1 \mathrm{M} \mathrm{HCl}$ solution to optimize the conditions for the Fenton reaction, similar to previous studies (Ifelebuegu \& Ezenwa, 2011; Zhao et al., 2010).

\subsection{Experimental design}

The performance evaluation of the BEF system in the batch experiments was done based on different MLSS concentrations. The seed sludge inocula with different MLSS concentrations were achieved by adjusting settling time. According to the settling time four sludge inocula with different MLSS concentration (500, 1000, 1500 and $3000 \mathrm{mg} \mathrm{L}^{-1}$ ) were obtained. The performances of Nafion 112 and Nafion 115 and the salt bridge in the BEF system with an air-cathode reactor and optimum inoculation of the anode anaerobic sludge (obtained in aforementioned experiments) were investigated. Finally, the effect of the initial amount of $\mathrm{FeCl}_{3} \cdot 6 \mathrm{H}_{2} \mathrm{O}(0.7,0.9$ and $1.1 \mathrm{~g})$ as an iron source for power generation and COD removal was studied with MLSS concentration and the kind of Nafion in optimum conditions.

\subsection{Analytical methods}

In all experiments, samples $(5 \mathrm{~mL})$ were taken every $12 \mathrm{~h}$ from the chambers to be analyzed for the final values of $\mathrm{pH}$, MLSS concentration and COD removal. Samples were filtered through a Whatman filter (pore size $0.2 \mu \mathrm{m}$ ). The initial and final COD of wastewater was measured using a calorimetric method with closed reflux (the Palintest system, photometer 8000, England) at $600 \mathrm{~nm}$, employed to measure the absorbance of COD samples (APHA, 1998). The COD removal percentage during operation was determined according to the following equation:

$R=\frac{C_{i}-C_{f}}{C_{i}} \times 100$ 
where $R$ is the COD removal $\%, C_{\mathrm{i}}$ the initial concentration of COD in $\mathrm{mg} \mathrm{L}^{-1}$ and $C_{\mathrm{f}}$ the final concentration of COD in $\mathrm{mg} \mathrm{L}^{-1}$. The $\mathrm{pH}$ values of the medicinal herbs wastewater were measured using a HANNA (Romania) model pH meter glass electrode set. Sodium hydroxide $(1 \mathrm{M})$ and hydrochloric acid solution $(1 \mathrm{M})$ were used to adjust the initial $\mathrm{pH}$ of this wastewater. The concentration of the total iron ions $\left(\mathrm{Fe}^{2+}\right.$ and $\left.\mathrm{Fe}^{3+}\right)$ in the solution was determined after their reaction with 1,10-phenantroline (Li et al., 2009) using a Unico double beam UV/Visible spectrophotometer (Unico 4802, USA) at a wavelength of $510 \mathrm{~nm}$ and the concentration of $\mathrm{H}_{2} \mathrm{O}_{2}$ generated in the cathode chamber by a photometric analysis (Palintest 800 , England) at $520 \mathrm{~nm}$. The cell voltage outputs of the BEF reactors were continuously recorded in real time using an analog digital data logger and a computer connected to the system. The power performance of the system was evaluated by the polarization curves. In the batch mode operation, the polarization curves were obtained at steady state condition while setting an adjustable resistance $(100$ to $100000 \Omega$ ) in the data logger (Rahimnejad et al., 2012). The power density $\left(\mathrm{mW} \mathrm{m}^{-2}\right)$ and current density $\left(\mathrm{mA} \mathrm{m}^{-2}\right)$ was calculated according to:

$P=\frac{I V}{A}$

$I=\frac{V}{R A}$

where $P$ is the power density and $V$ the measured cell voltage; $R$ denotes the electrical resistance, $I$ indicates the produced current and $A$ is the cathode area of the electro-Fenton reactors $\left(11.25 \mathrm{~cm}^{2}\right)$. The current in the BEF reactors was automatically calculated and recorded dividing the obtained voltage by the specified resistance. Then, the power provided by the system is calculated by multiplication of voltage and current (Rahimnejad et al., 2011). The percentage of electrons recovered as current is referred to as columbic efficiency, $\epsilon_{\mathrm{cb}}$, calculated as the ratio of total coulombs shifted to the anode from the COD to the theoretical 
amount of Coulombs available that can be produced from all organic matter removal. The coulombic efficiency is given using:

$\epsilon_{c b}=\frac{\text { Coulombs recovered }}{\text { Theoretical amount of Coulombs in COD }}$

Therefore, the total Coulombs transferred in the MFC system can be determined by integrating the current over time, so that the coulombic efficiency for the MFC run in batch mode can be calculated by the following equation:

$\epsilon_{c b}=\frac{M \int_{0}^{t} I d t}{F b v_{A n} \Delta C O D} \times 100$

where, $\epsilon_{\mathrm{cb}}$ is the percentage coulombic efficiency (\%), $M\left(=32 \mathrm{~g} \mathrm{O}_{2} \mathrm{~mol}^{-1} \mathrm{O}_{2}\right)$ is the molecular weight of oxygen, $t$ the time of experiment (s), $I$ is the average current output of the MFC (A), $F$ is the Faraday's constant $\left(96485 \mathrm{C} \mathrm{mol}^{-1} \mathrm{e}^{-}\right), b\left(=4 \mathrm{~mol} \mathrm{e}^{-} \mathrm{mol}^{-1} \mathrm{O}_{2}\right)$ the number of electrons exchanged per mole of oxygen, $v_{\text {An }}$ the volume of liquid in the anode chamber for batch operation (L) and $\triangle \mathrm{COD}$ the change in organic matter for the batch operation over a time $\left(\mathrm{mg} \mathrm{L}^{-1}\right)$. For MFC that run in a batch mode condition, the coulombic efficiency can be stated in the following equation:

$\epsilon_{c b}=\frac{8 I t}{F v_{A n} \triangle C O D}$

The energy conversion recovery $\left(\epsilon_{\mathrm{E}}\right)$ was calculated as the ratio of power produced by the cell over a time interval $t$ to the energy content of the COD consumed. The energy conversion efficiency is given using:

$\epsilon_{E}=\frac{\int_{0}^{t} E_{\text {cell I }} \mathrm{dt}}{\Delta H m_{\text {consumed }}}$

where, $E_{\text {cell }}$ is the measured cell voltage (V), $\Delta \mathrm{H}\left(=13.9 \mathrm{~kJ} \mathrm{~g}^{-1} \mathrm{COD}\right)$ the heat of combustion values for wastewater calculated from the COD and $m_{\text {consumed }}$ the amount of COD consumed (g).

The surface morphology of the anode electrode before and at the end of the experiment was examined using a scanning electronic microscope (SEM, KYKY EM 3200, China). Samples 
were pre-treated overnight with $2 \%(\mathrm{v} / \mathrm{v})$ glutaraldehyde to fix the bacteria on the surface of the graphite $\left(\mathrm{pH} 7.5,4^{\circ} \mathrm{C}\right)$, followed by the subsequent dehydrating using increasing water/alcohol solution (30 to70\%, v/v). The electrode was covered with gold by a gold sputtering device to provide better visibility of the surface morphology. Finally, SEM images of the samples were taken at a magnification of 2500 times at a voltage of $25 \mathrm{kV}$.

\section{Results and discussion}

\subsection{Power generation from medicinal herbs wastewater in BEF reactor}

Preliminary experiments performed by a two chambered BEF, demonstrated that using medicinal herbs wastewater, electricity was generated and that the microorganisms needed were already present in the wastewater. Batch manner of functioning is necessary to determine the best conditions to reach the maximum electrical output (Rahimnejad et al., 2012). The performance of the BEF system was evaluated by the polarization curve, which was recorded to determine the maximum power generation in the batch BEF system and the power density normalized to the projected cathode surface area or the reactor volume. Fig. 2 compares the voltage output and power density curves for the coupled system at a different MLSS (produced biological mass). Fig. 2a shows that the maximum power density of 60.43 $\mathrm{mW} \mathrm{m} \mathrm{m}^{-2}$ and maximum current density of $550.21 \mathrm{~mA} \mathrm{~m}^{-2}$ at MLSS $3000 \mathrm{mg} \mathrm{L}^{-1}$ were obtained. Also the power densities are $25.51 \mathrm{~mW} \mathrm{~m}^{-2}$ at the MLSS $500 \mathrm{mg} \mathrm{L}^{-1}, 37.64 \mathrm{~mW} \mathrm{~m}^{-}$ 2 at the MLSS $1000 \mathrm{mg} \mathrm{L}^{-1}$ and $49.76 \mathrm{~mW} \mathrm{~m}^{-2}$ at the MLSS $1500 \mathrm{mg} \mathrm{L}^{-1}$ (Fig. 2a). The results showed that the activated sludge is a suitable biocatalyst for electricity generation, according to previous studies (Min et al., 2005; Sun et al., 2009; Xu et al., 2011). In the present study, infinite resistance was used to obtain the open circuit voltage (OCV) in different MLSS in the batch systems. The initial voltages were low due to both chemical and biological factors, based on the differences of the electrical potential between the two 
chambers, but the cell voltage gradually increased due to biological activity, reaching a steady state and the maximum value (optimum condition: $600 \mathrm{mV}$ in MLSS $3000 \mathrm{mg} \mathrm{L}^{-1}$ ) after $48 \mathrm{~h}$, suggesting that a stable microbial community had colonized in the anode chamber (Fig. 2b). A similar increase in the primary voltage of microbial fuel cells has been reported by different sources of organic matters (Ai et al., 2007b; Li et al., 2009; Sánchez-Sánchez et al., 2007). However, the increase in MLSS in the anode chamber showed positive influence on the power output. Specifically the operating system at higher MLSS demonstrated relatively good bioelectricity production for an extended period of time. Previous researchers have also illustrated that the substrate, and maybe the bacterial community that develops during adoption, affect microbial activities and therefore also affects the maximum power density attained from the wastewaters (Güven et al., 2008; Min et al., 2005). The enhancement of bioelectricity production in the present study, realized by the continuous generation of electrons and protons along with the organic matter degradation by the microorganisms (Özcan et al., 2008), is due to the fact that the electrical energy obtained from the BEF reactor can be utilized for in situ generation of Fenton's reaction and hydroxyl radical generation through decomposition of $\mathrm{H}_{2} \mathrm{O}_{2}$ to water (Özcan et al., 2008; Wang et al., 2008). Subsequently, the effect of the Nafion 112 on the performance of dual-chamber BEF reactor was examined at the optimum MLSS $\left(3000 \mathrm{mg} \mathrm{L}^{-1}\right)$ in a batch-fed mode and compared to the Nafion 115 and the salt bridge configurations. Comparing the maximum power density of each of the BEF reactors revealed the Nafion 112 to be useful for power generation, the BEF reactor with Nafion 112 having a maximum power density of $60.43 \mathrm{~mW}$ $\mathrm{m}^{-2}$ at a current density of $350.25 \mathrm{~mA} \mathrm{~m}^{-2}$, higher than that of Nafion $115\left(38.29 \mathrm{~mW} \mathrm{~m}^{-2}\right)$ and much higher than the BEF reactor with a salt bridge $\left(8.74 \mathrm{~mW} \mathrm{~m}^{-2}\right)$ (Fig. 3a). The voltage generation shown in Fig. 3b, the BEF reactor with Nafion 112 generates the high voltage $(600 \mathrm{mV}), 60 \%$ and $178 \%$ higher than that generated by the BEF reactor with Nafion 115 
$(376 \mathrm{mV})$ and the salt bridge $(216 \mathrm{mV})$, respectively. The obvious improvement in the performance of the dual chamber BEF by using Nafion 112 in the cathode may be due to its high permeability that facilitates charge transfer better than other Nafion membranes (Sun et al., 2009). These experimental results revealed that the use of two kinds of Nafion, including Nafion 115 and 112 with respective thicknesses of $125 \mu \mathrm{m}$ and $50 \mu \mathrm{m}$, in an MFC demonstrated that the cell performance increased with decreasing membrane thickness as a result of higher power density at a higher current density.

\subsection{COD removal through anodic biooxidation of BEF reactor}

Batch experiments were performed to find the parameters to be considered for the optimum conditions such as the amount of MLSS and type of Nafion membrane both in the anode and the cathode chamber for maximum wastewater treatment. The performance of the coupled system in utilizing medicinal herbs wastewater was studied on the basis of the removal efficiency of COD. In wastewater, the carbon fraction acts as an electron donor in the metabolic process and causes the degradation of the substrate simultaneously to power generation (Mohanakrishna et al., 2010). In the anodic chamber, there is an anaerobic

condition which microbial degradation of organic materials coupled with electron transfer to the anode electrode and poton transfer to the cathodic chamber through the proton exchange membrane (Moon et al., 2006; Rahimnejad et al., 2014). As pH 7 is the best for microorganism activity in anaerobic condition (Gil et al., 2003; Li et al., 2008), in this study, the $\mathrm{pH}$ of wastewater in the anodic chamber was adjusted at $\mathrm{pH}=7$. In similar studies carried out by Gil et al. (Gil et al., 2003) and Li et al. (Li et al., 2008), the highest current and COD removal were achieved at $\mathrm{pH}=7$, showing that at a lower $\mathrm{pH}$ microbial activity is slower. In the coupled system, the medicinal herbs wastewater is partly biodegraded in the anode chamber, as shown by the results of COD removal in different MLSS concentrations, 
presented in Fig. 4. In MLSS $3000 \mathrm{mg} \mathrm{L}^{-1}$, the anode side achieved a maximum COD removal of $78.05 \%$, while with MLSS 500, 1000 and $1500 \mathrm{mg} \mathrm{L}^{-1}$, the removals of COD were a little lower, being 51.43, 62.84 and $70.39 \%$, respectively. The anodic chamber of the MFC functions as a suspended growth anaerobic reactor, which is an indicator of the high potential of MFC as replacement with biological treatment processes (Moon et al., 2006; Venkata Mohan et al., 2008a; Venkata Mohan et al., 2008b). The results obtained indicated that using seed sludge as microbial source and wastewater as fuel achieved the best performance, and there being no need to add another microbial source, which was the result Ahn and Logan (Ahn \& Logan, 2010) and Greenman et al. (Greenman et al., 2009) also reached in their studies. In the BEF reactor, the medicinal herbs wastewater showed higher substrate degradation efficiency, which further degradation by microorganisms may be caused by two mechanisms: (a) direct oxidation (DO) where the pollutants are adsorbed on the anode surface and degraded by the electrons that get transferred to the anodic chamber (Güven et al., 2008), (b) indirect oxidation (IO), whereby the organic matter is degraded by the oxidants such as chlorine dioxide, hypochlorite, hydroxyl radicals, ozone and hydrogen peroxide formed electrochemically on the anode surface (Mohanakrishna et al., 2010). In the beginning the substrate gets oxidized during the DO process, forming primary oxidant species on the anode surface. These oxidants react further on the anode and produce secondary oxidants, generating the IO process. The secondary oxidants have a significant influence on the COD removal efficiency (Israilides et al., 1997). The MLSS production curves in anaerobic conditions with different initial MLSS were studied and compared, as shown in Fig. 5. In this study, the maximum cell production $\left(6044 \mathrm{mg} \mathrm{L}^{-1}\right)$ is obtained in a 48 $\mathrm{h}$ period. The results indicate that high initial MLSS, due to greater microbial activity, leads to the production of high voltage, power and current, which consequently leads to high COD removal in the BEF reactor. 


\subsection{COD removal through cathodic bioelectro-Fenton Reaction}

The medicinal herbs wastewater is generally characterized by a high concentration of organic pollutants, which could not be completely removed from the anode chamber through biooxidation by microorganisms. In the first stage, the $\mathrm{pH}$ value of the influent in the cathodic chamber was adjusted at 3 frequently during treatment, as the previous studies had shown that the optimum $\mathrm{pH}$ value of the Fenton- reaction was in the range of 3- 4 (Galehdar et al., 2009; Zhao et al., 2010). Fig. 4 shows the COD removal of the medicinal herbs wastewater in the cathode chamber at pH 3 within $50 \mathrm{~h}$; as observed, this wastewater was separately treated in the anode chamber. In this Figure, the COD removal rate with MLSS of 500, 1000, 1500 and $3000 \mathrm{mg} \mathrm{L}^{-1}$ is $57.50,68.80,78.42$ and $84.02 \%$, respectively. Moreover, with the optimum MLSS concentration (3000 $\mathrm{mg} \mathrm{L}^{-1}$ ), the effect of the Nafion membrane on the COD removal in the cathode chamber was investigated. Fig. 6 shows the COD removal curves of three BEF reactors with different Nafion membranes. It is clear that there is a relationship between time and COD removal. The higher values were obtained when the time was increased and it should be noted that the COD removal rate in the cathode chamber (except in the reactor with a salt bridge due to the low permeability and low formation of oxidants) was more than in the anode chamber because during the Fenton process occuring on the cathode side, hydrogen peroxide decomposes in the presence of ferrous ions and produces hydroxyl radicals with a high oxidation capacity (Satishkumar et al., 2013). In addition, BEF reactor can supply the electricity necessary to drive the electro-Fenton process. These properties allow the reproduction of Fenton's reaction in the cathode chamber and the high degradation of organic pollutants (Fernández de Dios et al., 2013). The results obtained in this study about COD removal are in accordance with other previous studies of researchers such as Beltran de Heredia et al. (de Heredia et al., 2005). Their results demonstrated that the COD removal efficiency decreased with the increase of components of Fenton reagents. The reason for this 
phenomenon could be due to the presence of the inorganic and organic iron ligands in the waste occupying the active sites of iron, with a potential influence on the Fenton reaction, or because a lack of a sufficient amount of oxidants (Hadavifar et al., 2010). The results obtained, indicate that in the bio-electro-Fenton reactor the operating cost was already greatly reduced without the requirement of the external energy supply, so it is an alternative to indirect electro-oxidation of pollutants of the effluent.

\subsection{In situ generation of $\mathrm{H}_{2} \mathrm{O}_{2}$ and $\mathrm{Fe}$ in the cathode chamber}

In our dual-chamber fuel cells, $\mathrm{H}_{2} \mathrm{O}_{2}$ was generated through an electrochemical reaction of oxygen dissolved in the cathode chamber with the electron transferred from the anode microbial activity and continuous generation of $\mathrm{H}_{2} \mathrm{O}_{2}$ is obtained via the two-electron reduction of dissolved $\mathrm{O}_{2}$ at the cathode (Eq (1)) (Feng et al., 2010b; Özcan et al., 2008). The detectable amounts of $\mathrm{H}_{2} \mathrm{O}_{2}$ and $\mathrm{Fe}$ ions present in the cathode are evidenced for the two kinds of cathodic reactions (Fig. 7). These reactions include the electrochemical reduction of dissolved oxygen to $\mathrm{H}_{2} \mathrm{O}_{2}$ and corrosion of the zerovalent iron $\mathrm{Fe} @ \mathrm{Fe}_{2} \mathrm{O}_{3}$ to ferrous iron $(\mathrm{Fe}$ ${ }^{2+}$ ) (Feng et al., 2010b). As can be seen in Fig. 7a, after the starting-up period of BEF reactors, there is an increase in $\mathrm{H}_{2} \mathrm{O}_{2}$ concentration and gradually approaches steady state when its generation rate equals that of its decomposition. These results were confirmed by other researchers (Feng et al., 2010b). The concentrations of $\mathrm{H}_{2} \mathrm{O}_{2}$ in the cathode chamber reactions after $50 \mathrm{~h}$ were $0.39,0.47,0.56,0.62$ and 0.49 and $0.28 \mathrm{mg} \mathrm{L}^{-1}$ corresponding to the MLSSs of 500, 1000, 1500 and $3000 \mathrm{mg} \mathrm{L}^{-1}$ with Nafion 112, the MLSS 3000 with Nafion 115 and the salt bridge, respectively. As shown in Fig. 7a, the BEF reactor with MLSS of $3000 \mathrm{mg} \mathrm{L}^{-1}$ and Nafion 112 demonstrate better performance for $\mathrm{H}_{2} \mathrm{O}_{2}$ electro-generations than the others, indicating the high efficiency of the electro-Fenton process. The differences in the values of the $\mathrm{H}_{2} \mathrm{O}_{2}$ concentrations reveal the levels of hydroxyl radicals for pollutant 
degradation, as explained in the previous section. Similarly, Zhuang et al. (Zhuang et al., 2010b) created a bioelectro-Fenton system in their study, using a $\mathrm{Fe} @ \mathrm{Fe}_{2} \mathrm{O}_{3} /$ carbon felt composite cathode and discovered that an increase in the cathodic current density led to a favorable $\mathrm{H}_{2} \mathrm{O}_{2}$ production. Moreover, the concentrations of $\mathrm{Fe}^{2+}$ are an important factor to limit the reaction rate of pollutant degradation (Feng et al., 2010b). The generated $\mathrm{H}_{2} \mathrm{O}_{2}$ is almost consumed by reacting with the iron agent and the formation of oxidants. Along with the formation of hydroxyl radicals, wastewaters are further oxidized in the cathode chamber (Xu et al., 2011). In this study, the $\mathrm{Fe}^{2+}$ is produced from corrosion of $\mathrm{Fe} @ \mathrm{Fe}_{2} \mathrm{O}_{3}$ and reacts with $\mathrm{H}_{2} \mathrm{O}_{2}$ to form $\mathrm{Fe}^{3+}$. Fig. $7 \mathrm{~b}$ shows the total iron ion concentration in different BEF reactors as a function of time. In accordance with these curves, the BEF reactor with MLSS $3000 \mathrm{mg} \mathrm{L}^{-1}$ and Nafion 112 indicate the highest concentration of Fe compared with the other reactors, a steady level of iron ion being around $31 \mathrm{mg} \mathrm{L}^{-1}$ within 70 hours of operation. Also the molar ratio of $\mathrm{Fe} / \mathrm{H}_{2} \mathrm{O}_{2}$ in the different $\mathrm{BEF}$ reactors was measured that with an increasing $\mathrm{Fe} / \mathrm{H}_{2} \mathrm{O}_{2}$ molar ratio leading to the decrease of the COD removal percentage in cathodic chambers. In the present study, it was observed that a lesser $\mathrm{Fe} / \mathrm{H}_{2} \mathrm{O}_{2}$ molar ratio is more effective for the reduction of COD in medicinal herbs wastewater. At a higher $\mathrm{Fe} / \mathrm{H}_{2} \mathrm{O}_{2}$ molar ratios, due to the existence of a lower amount of $\mathrm{H}_{2} \mathrm{O}_{2}$, or an excess amount of $\mathrm{Fe}$ ions in the reaction vessel, the COD removal percentage decreases. This causes a low production of hydroxide radicals and reduction in the decomposition of organic matter (Galehdar et al., 2009). Beltran de Heredia et al. (de Heredia et al., 2005) have reported that an increase in COD removal efficiency was obtained for a molar ratio of $\mathrm{Fe} / \mathrm{H}_{2} \mathrm{O}_{2}=0.1$ and then decreased with an increase in the molar ratio $\left(\mathrm{Fe} / \mathrm{H}_{2} \mathrm{O}_{2}=0.3\right)$. To investigate the influence of total iron ion concentration on COD removal and power generation, additional experiments were conducted in the cathode chamber of the BEF reactor with a different amount of $\mathrm{FeCl}_{3}-6 \mathrm{H}_{2} \mathrm{O}$, used to construct the $\mathrm{Fe} @ \mathrm{Fe}_{2} \mathrm{O}_{3}$ /graphite composite cathode. Figs. 8a and b show the changes 
in the amount of $\mathrm{FeCl}_{3}-6 \mathrm{H}_{2} \mathrm{O}$ for power generation and $\mathrm{COD}$ removal. Increasing the amount of iron chloride from 0.7 to $0.9 \mathrm{~g}$, due to more Fe being released, caused an increase in power density from 38.34 to $60.43 \mathrm{~mW} \mathrm{~m}^{-2}$. This in turn improved the rate of COD removal from 78.85 to $84.02 \%$. It is evident from these curves that by increasing this value from 0.9 to 1.1 $\mathrm{g}$, although the Fe produced remained almost stable, power density and COD removal were decreased. In general, the results of batch experiments in electricity generation and COD removal of medicinal herbs wastewater in different BEF reactors are shown in Table 2. The $\mathrm{BEF}$ system was operated in a batch mode for $96 \mathrm{~h}$ at room temperature $\left(\sim 25^{\circ} \mathrm{C}\right)$ and $\mathrm{pH}=7$ with medicinal herbs wastewater having an influent total COD of $6183 \pm 309 \mathrm{mg} \mathrm{L}^{-1}$. As can be seen in the table, with the MLSS concentration of $3000 \mathrm{mg} \mathrm{L}^{-1}$ and the amount of iron chloride at $0.9 \mathrm{~g}$ using Nafion 112, the effluent total COD was reduced to $1360.26 \pm 68.01$ $\mathrm{mg} \mathrm{L}^{-1}$ (78\% removal) in the anaerobic anode chamber, and there was a removal of about a total of $84 \%$ COD (from $6183 \pm 309 \mathrm{mg} \mathrm{L}^{-1}$ to $989.28 \pm 49.46 \mathrm{mg} \mathrm{L}^{-1}$ ) in the aerobic processes of the air-cathode BEF chamber. The table shows that the amount of COD removal increased with an increase in the MLSS concentration from 500 to $3000 \mathrm{mg} \mathrm{L}^{-1}$, the maximum generation of current density $\left(550.21 \mathrm{~mA} \mathrm{~m}^{-2}\right)$, voltage $(600 \mathrm{mV})$ was achieved in the amount of initial $\mathrm{FeCl}_{3}-6 \mathrm{H}_{2} \mathrm{O} 0.9 \mathrm{~g}$ at cathodic neutral $\mathrm{pH}$. In the absence of a buffer, the pH was substantially increased above neutral pH (Nam \& Logan, 2012).

\subsection{Effect of pH on power generation on cathode chamber}

The Nernst equation has a physiological application when used to evaluate the effect of catholyte $\mathrm{pH}$ for maximum possible potential of an ion of charge $z$ across a membrane (Kim \& Logan, 2013):

$E=E^{o}+\frac{R T}{z F} \ln \frac{[O x]}{[R e d]}$ 
where $E$ is the cell potential at the temperature of interest, $E^{\circ}$ the standard cell potential, $R$ the gas constant $\left(R=8.314 \mathrm{~J} \mathrm{~K}^{-1} \mathrm{~mol}^{-1}\right), T$ the absolute temperature $(\mathrm{K}), F$ the Faraday constant $\left(96486 \mathrm{C} \mathrm{mol}^{-1}\right), z$ the number of moles electrons transfer in the half-reaction, (Ai et al.) the oxidizing species (e.g., $\mathrm{O}_{2}$ or $\mathrm{H}^{+}$) and (de Heredia et al.) the reducing species (e.g., $\mathrm{H}_{2} \mathrm{O}_{2}$ ) in the half-cell electrode reactions. Because $\mathrm{RT} / \mathrm{F}=25.7 \mathrm{mV}$ at $298 \mathrm{~K}$, the standard potential of a cell is related to the standard reaction Gibbs energy through Eq. (14) at equilibrium $(E=0)$, a special form of the Nernst equation is:

$E^{o}=-\frac{59.2 m V}{z} p H$

The Nernst equation shows that the cathode potential would decrease with the increasing of $\mathrm{pH}$. For oxygen reduction (Eq (1)) and hydrogen evolution (Eq (2)) reactions, the cell potential can be changed by $(-59.2 / z) \mathrm{mV}$ for each unit change in the value of $\mathrm{pH}$ (for each 10 -fold change in the value of $\mathrm{H}^{+}$activity). The results in Table 2 demonstrated this conclusion that the $\mathrm{pH}$ value sustainably increased, and the cell potential therefore steadily increased. Furthermore, the $\mathrm{pH}$ value of catholyte was closely related to the reactions responsible for the generation of $\mathrm{H}_{2} \mathrm{O}_{2}, \mathrm{Fe}^{2+}$ and $\mathrm{HO}^{\circ}$ according to Eqs (1) to (6), and consequently the efficiency of Fenton reaction. On the other hand, using the same anode in an MFC system with different cathode conditions (Eqs. 2-6) would have a significant effect on the cell voltage produces, and thus have a different power output. This confirms the results shown in Table 2 that $\mathrm{pH}$ significantly influences the efficiency of Fenton reaction and the final $\mathrm{pH}$ was in neutral conditions and the final $\mathrm{pH}$ of catholyte was higher than initial $\mathrm{pH}$. As shown in Table 2, maximum COD removal efficiency of medicinal herbs wastewater was also obtained at neutral final $\mathrm{pH}$. On the other hand, the high removal of COD may consume more hydrogen ions and led to the higher final $\mathrm{pH}$.

\subsection{Columbic efficiency and energy recovery}


While treating wastewater and generating power were the main objective of the present study, we also investigated extracting as much of the electrons stored in the biomass as possible current, and to recover as much energy as possible from the system. For comparison purposes, reported energy recovery in the MFC system varies from 2 to $50 \%$ when easily biodegradable substrates (electron donor), such as glucose, acetate, amino and organic acid, are used. The electric energy recovery of about $40 \%$ was reported for thermal conversion of methane (Lu et al., 2009; Rabaey et al., 2003). The produced electron in the BEF and MFC system consumed for (a) power output, that the time integral of current was caused by formation of electrons used in power output, (b) bio-electro-Fenton reaction, that the part of electrons was reacting with $\mathrm{O}_{2}$ and proton to produce $\mathrm{H}_{2} \mathrm{O}_{2}$, (c) the other electron acceptors, that consumed the residual electrons to allow significant degradation (Gil et al., 2003; Li et al., 2008). As can be seen in Table 2, the $\epsilon \mathrm{cb}$ was below $0.65 \%$ using salt bridge and increased up to $3.56 \%$ and $4.09 \%$ using Nafion 112 with $1500 \mathrm{mg} \mathrm{L}^{-1}$ MLSS and the same reactor fed with $3000 \mathrm{mg} \mathrm{L}^{-1}$ MLSS respectively. The $\epsilon_{\mathrm{E}}$ was computed with respect to the energy content of the consumed COD in anode chamber. The $\epsilon_{\mathrm{E}}$ based on the difference in COD between influent and effluent reached values from 1.19 to $1.37 \%$ using Nafion 112 with $1500 \mathrm{mg} \mathrm{L}^{-1}$ MLSS and the same reactor fed with $3000 \mathrm{mg} \mathrm{L}^{-1}$ MLSS respectively. These $\epsilon_{\mathrm{cb}}$ and $\epsilon_{\mathrm{E}}$ are considered very low when compared to columbic efficiency and energy recovery values for MFC operated with easily biodegradable substrate. The reason for this is probably due to the consumption of a considerable part of electrons produced from the bio-oxidation of organic materials by bio-electro-Fenton reaction in the cathode side (Eqs. 2-6) and to nonelectrogenic side reactions (Xu et al., 2011). However, $\epsilon \mathrm{cb}$ and $\epsilon \mathrm{E}$ values obtained obtained hereunder, the batch conditions were comparable to those previously reported for fed-batch and continuous conditions (Lu et al., 2009; Rabaey et al., 2003; Xu et al., 2011). Xu et al. (Xu et al., 2011) reported $\epsilon \mathrm{cb}$ values between $6.5-4.0 \%$ in continuous BEF system. They have 
used Swine wastewater as substrate and GORE-TEX® as the proton exchange membrane. Additionally, the MFC systems powered with a simple substrate such as glucose and acetate show high $\epsilon_{\mathrm{cb}}$ compared to that obtained here with a medicinal herbs wastewater treatment (Ai et al., 2007b). Rahimnejad et al. (Rahimnejad et al., 2011) reported a $\epsilon_{\mathrm{cb}}$ value of $13 \%$ using by glucose as substrate in the MFC system that the breakdown of sugars by microorganism resulted in the production of some intermediate which can play an important role in reduction of $\epsilon_{\mathrm{cb}}$ (Rahimnejad et al., 2012). Therefore, these results illustrate that the electricity produced in the BEF reactor during the treatment medicinal herbs wastewater can be used simultaneously in the wastewater treatment process.

\subsection{SEM analysis of anode electrode}

SEM studies were performed to examine the physical morphology of the electrode surface and to examine the growth of microorganisms on the anode surface. Fig. 9a and b shows the two SEM images of the surface of anode electrode before and after use in the MFC. It was observed that the SEM image of the anode in the anaerobic chamber before use, of which get a good polish on the outer surface of the electrode (Fig. 9a). Fig. 9b shows the outer surface of the graphite electrode at the end of experimental runs, demonstrating that microorganisms have grown on the graphite surface. When viewed on the electrode surface, it is realistic to conclude that the particulates visible in SEM are due to growth or cluster of microorganisms.

\section{Conclusion}

The BEF system equipped with a $\mathrm{Fe} @ \mathrm{Fe}_{2} \mathrm{O}_{3} /$ graphite composite cathode represents a new approach to wastewater treatment coupled with simultaneous bioelectricity generation. In this study, bioelectricity production from medicinal herbs wastewater with simultaneous removal of COD in a novel bio-electro-Fenton reactor was successfully carried out in a batch mode. 
The results showed that a BEF reactor with a higher MLSS and the permeable Nafion lead to improving the power performance. Furthermore, we found that by applying this BEF system in an MFC equipped with $\mathrm{Fe} @ \mathrm{Fe}_{2} \mathrm{O}_{3}$ /graphite composite cathode as a power source to drive the electro-Fenton process at $\mathrm{pH} 3.0$, successfully proved to be applicable to remove significant amounts of COD and with showing a stronger oxidation capacity. This was shown by the fact that under optimal conditions, the BEF reactor equipped with $\mathrm{Fe} @ \mathrm{Fe}_{2} \mathrm{O}_{3} /$ graphite composite cathode $\left(0.9 \mathrm{~g} \mathrm{FeCl}_{3}-6 \mathrm{H}_{2} \mathrm{O}\right)$, MLSS with $3000 \mathrm{mg} \mathrm{L}^{-1}$ and Nafion 112, had the highest OCV $(600 \mathrm{mV})$, the highest power density $\left(60.43 \mathrm{~mW} \mathrm{~m}^{-2}\right), \epsilon_{\mathrm{cb}}(4.09 \%)$ and $\epsilon_{\mathrm{E}}$ (1.37\%) between the other BEF reactors investigated. This reactor also generated a high concentration of $\mathrm{H}_{2} \mathrm{O}_{2}$ and hydroxyl radicals, causing the destruction of the organic pollutants. A decrease in the $\mathrm{Fe} / \mathrm{H}_{2} \mathrm{O}_{2}$ molar ratio resulted in an increase in the COD removal efficiency, over $84 \%$ of COD was removed from medicinal herbs wastewater in this BEF reactor. This process was economical and effective for continuous power generation and degradation of recalcitrant contaminants without additional commercial reagents and energy requirements. This study demonstrates the potential application of the BEF system in wastewater treatment, because it can be used not only for the treatment of biodegradable organic materials in the anode, but also for the treatment of non-biodegradable ones in the cathode. The advantage of this treatment approach is the possibility of having all processes occur in a single system, which might have a positive influence on the overall efficiency of the process. Finally, the potential application of MFC in the near future is considered promising and economically feasible for this technology to achieve electricity generation and sustainable wastewater treatment on a large scale.

\section{Acknowledgements}


This work is financially supported by the Iran National Science Fundation (projects No.

94011845). The authors wish to thank Tarbiat Modares University (TMU) and the Ministry

of Science and Technology for their financial support, Mrs. Haghdoust (Technical assistant in

Environmental Laboratory) for her valuable technical assistance in the laboratory, and Ellen

Vuosalo Tavakoli (University of Mazandaran) for revising and editing the English text.

\section{References}

Ahn, Y., Logan, B.E. 2010. Effectiveness of domestic wastewater treatment using microbial fuel cells at ambient and mesophilic temperatures. Bioresour. Technol., 101(2), 469-475.

Ai, Z., Mei, T., Liu, J., Li, J., Jia, F., Zhang, L., Qiu, J. 2007a. Fe@ Fe2O3 core-shell nanowires as an iron reagent. 3. Their combination with CNTs as an effective oxygen-fed gas diffusion electrode in a neutral electro-Fenton system. The Journal of Physical Chemistry C, 111(40), 14799-14803.

Ai, Z., Mei, T., Liu, J., Li, J., Jia, F., Zhang, L., Qiu, J. 2007b. Fe@ $\mathrm{Fe}_{2} \mathrm{O}_{3}$ core-shell nanowires as an iron reagent. 3. Their combination with CNTs as an effective oxygen-fed gas diffusion electrode in a neutral electro-Fenton system. The Journal of Physical Chemistry C, 111(40), 14799-14803.

APHA. 1998. Standard methods for the examination of water and wastewater, 20th edn. American Public Health Association Publications, Washington DC.

Birjandi, N., Younesi, H., Ghoreyshi, A.A., Rahimnejad, M. 2015. Electricity generation, ethanol fermentation and enhanced glucose degradation in a bio-electro-Fenton system driven by Microbial fuel cell. Journal of Chemical Technology \& Biotechnology, 91(6), 1868-1876.

Cheng, J., Zhu, X., Ni, J., Borthwick, A. 2010. Palm oil mill effluent treatment using a two-stage microbial fuel cells system integrated with immobilized biological aerated filters. Bioresour. Technol., 101(8), 2729-2734.

Daneshi, A., Younesi, H., Ghasempouri, S.M., Sharifzadeh, M. 2010. Production of poly-3hydroxybutyrate by Cupriavidus necator from corn syrup: statistical modeling and optimization of biomass yield and volumetric productivity. J. Chem. Technol. Biotechnol., 85(11), 1528-1539.

de Heredia, J.B., Torregrosa, J., Dominguez, J., Partido, E. 2005. Degradation of wine distillery wastewaters by the combination of aerobic biological treatment with chemical oxidation by Fenton's reagent. Sustainable Viticulture and Winery Wastes Management, 51(1), 167-174.

Fan, Y., Han, S.-K., Liu, H. 2012. Improved performance of CEA microbial fuel cells with increased reactor size. Energy \& Environmental Science, 5(8), 8273-8280.

Feng, C.-H., Li, F.-B., Mai, H.-J., Li, X.-Z. 2010a. Bio-electro-Fenton process driven by microbial fuel cell for wastewater treatment. Environ. Sci. Technol., 44(5), 1875-1880.

Feng, C., Li, F., Liu, H., Lang, X., Fan, S. 2010b. A dual-chamber microbial fuel cell with conductive film-modified anode and cathode and its application for the neutral electro-Fenton process. Electrochim. Acta, 55(6), 2048-2054.

Fernández de Dios, M.Á., del Campo, A.G., Fernández, F.J., Rodrigo, M., Pazos, M., Sanromán, M.Á. 2013. Bacterial-fungal interactions enhance power generation in microbial fuel cells and drive dye decolourisation by an ex situ and in situ electro-Fenton process. Bioresour. Technol., 148, 39-46.

Galehdar, M., Younesi, H., Hadavifar, M., Zinatizadeh, A.A. 2009. Optimization of a Photo-assisted Fenton Oxidation Process: A Statistical Model for MDF Effluent Treatment. CLEAN-Soil, Air, Water, 37(8), 629-637. 
Gil, G.-C., Chang, I.-S., Kim, B.H., Kim, M., Jang, J.-K., Park, H.S., Kim, H.J. 2003. Operational parameters affecting the performannce of a mediator-less microbial fuel cell. Biosensors Bioelectron., 18(4), 327-334.

Greenman, J., Gálvez, A., Giusti, L., leropoulos, I. 2009. Electricity from landfill leachate using microbial fuel cells: Comparison with a biological aerated filter. Enzyme Microb. Technol., 44(2), 112-119.

Güven, G., Perendeci, A., Tanyolaç, A. 2008. Electrochemical treatment of deproteinated whey wastewater and optimization of treatment conditions with response surface methodology. J. Hazard. Mater., 157(1), 69-78.

Hadavifar, M., Zinatizadeh, A.A., Younesi, H., Galehdar, M. 2010. Fenton and photo-Fenton treatment of distillery effluent and optimization of treatment conditions with response surface methodology. Asia-Pacific Journal of Chemical Engineering, 5(3), 454-464.

Ifelebuegu, A.O., Ezenwa, C.P. 2011. Removal of endocrine disrupting chemicals in wastewater treatment by Fenton-like oxidation. Water, Air, Soil Pollut., 217(1-4), 213-220.

Israilides, C.J., Vlyssides, A.G., Mourafeti, V.N., Karvouni, G. 1997. Olive oil wastewater treatment with the use of an electrolysis system. Bioresour. Technol., 61(2), 163-170.

Kim, Y., Logan, B.E. 2013. Microbial desalination cells for energy production and desalination. Desalination, 308, 122-130.

Li, J., Ai, Z., Zhang, L. 2009. Design of a neutral electro-Fenton system with $\mathrm{Fe}_{\mathrm{F}} \mathrm{Fe}_{2} \mathrm{O}_{3} / \mathrm{ACF}$ composite cathode for wastewater treatment. J. Hazard. Mater., 164(1), 18-25.

Li, Z., Yao, L., Kong, L., Liu, H. 2008. Electricity generation using a baffled microbial fuel cell convenient for stacking. Bioresour. Technol., 99(6), 1650-1655.

Lu, N., Zhou, S.-g., Zhuang, L., Zhang, J.-t., Ni, J.-r. 2009. Electricity generation from starch processing wastewater using microbial fuel cell technology. Biochem. Eng. J., 43(3), 246-251.

Luo, Y., Zhang, R., Liu, G., Li, J., Qin, B., Li, M., Chen, S. 2011. Simultaneous degradation of refractory contaminants in both the anode and cathode chambers of the microbial fuel cell. Bioresour. Technol., 102(4), 3827-3832.

Mashkour, M., Rahimnejad, M. 2015. Effect of various carbon-based cathode electrodes on the performance of microbial fuel cell. Biofuel Research Journal, 2(4), 296-300.

Min, B., Kim, J., Oh, S., Regan, J.M., Logan, B.E. 2005. Electricity generation from swine wastewater using microbial fuel cells. Water Res., 39(20), 4961-4968.

Mohanakrishna, G., Venkata Mohan, S., Sarma, P.N. 2010. Bio-electrochemical treatment of distillery wastewater in microbial fuel cell facilitating decolorization and desalination along with power generation. J. Hazard. Mater., 177(1-3), 487-494.

Moon, H., Chang, I.S., Kim, B.H. 2006. Continuous electricity production from artificial wastewater using a mediator-less microbial fuel cell. Bioresour. Technol., 97(4), 621-627.

Nam, J.-Y., Logan, B.E. 2012. Optimization of catholyte concentration and anolyte pHs in two chamber microbial electrolysis cells. Int. J. Hydrogen Energy, 37(24), 18622-18628.

Özcan, A., Şahin, Y., Savaş Koparal, A., Oturan, M.A. 2008. Carbon sponge as a new cathode material for the electro-Fenton process: Comparison with carbon felt cathode and application to degradation of synthetic dye basic blue 3 in aqueous medium. J. Electroanal. Chem., 616(12), 71-78.

Pham, T.H., Aelterman, P., Verstraete, W. 2009. Bioanode performance in bioelectrochemical systems: recent improvements and prospects. Trends Biotechnol., 27(3), 168-178.

Rabaey, K., Lissens, G., Siciliano, S.D., Verstraete, W. 2003. A microbial fuel cell capable of converting glucose to electricity at high rate and efficiency. Biotechnol. Lett., 25(18), 1531-1535.

Rahimnejad, M., Bakeri, G., Najafpour, G., Ghasemi, M., Oh, S.-E. 2014. A review on the effect of proton exchange membranes in microbial fuel cells. Biofuel Research Journal, 1(1), 7-15.

Rahimnejad, M., Ghoreyshi, A., Najafpour, G., Younesi, H., Shakeri, M. 2012. A novel microbial fuel cell stack for continuous production of clean energy. Int. J. Hydrogen Energy, 37(7), 59926000 . 
Rahimnejad, M., Ghoreyshi, A.A., Najafpour, G., Jafary, T. 2011. Power generation from organic substrate in batch and continuous flow microbial fuel cell operations. Applied Energy, 88(11), 3999-4004.

Sánchez-Sánchez, C.M., Expósito, E., Casado, J., Montiel, V. 2007. Goethite as a more effective iron dosage source for mineralization of organic pollutants by electro-Fenton process. Electrochem. Commun., 9(1), 19-24.

Satishkumar, G., Landau, M.V., Buzaglo, T., Frimet, L., Ferentz, M., Vidruk, R., Wagner, F., Gal, Y., Herskowitz, M. 2013. Fe/SiO2 heterogeneous Fenton catalyst for continuous catalytic wet peroxide oxidation prepared in situ by grafting of iron released from LaFeO3. Applied Catalysis B: Environmental, 138-139(0), 276-284.

Sun, J., Hu, Y., Bi, Z., Cao, Y. 2009. Improved performance of air-cathode single-chamber microbial fuel cell for wastewater treatment using microfiltration membranes and multiple sludge inoculation. J. Power Sources, 187(2), 471-479.

Venkata Mohan, S., Mohanakrishna, G., Reddy, B.P., Saravanan, R., Sarma, P.N. 2008a. Bioelectricity generation from chemical wastewater treatment in mediatorless (anode) microbial fuel cell (MFC) using selectively enriched hydrogen producing mixed culture under acidophilic microenvironment. Biochem. Eng. J., 39(1), 121-130.

Venkata Mohan, S., Mohanakrishna, G., Srikanth, S., Sarma, P.N. 2008b. Harnessing of bioelectricity in microbial fuel cell (MFC) employing aerated cathode through anaerobic treatment of chemical wastewater using selectively enriched hydrogen producing mixed consortia. Fuel, 87(12), 2667-2676.

Wang, A., Qu, J., Liu, H., Ru, J. 2008. Mineralization of an azo dye Acid Red 14 by photoelectroFenton process using an activated carbon fiber cathode. Applied Catalysis B: Environmental, 84(3-4), 393-399.

Wang, X.-Q., Liu, C.-P., Yuan, Y., Li, F.-b. 2014. Arsenite oxidation and removal driven by a bioelectro-Fenton process under neutral pH conditions. J. Hazard. Mater., 275, 200-209.

Xu, N., Zhang, Y., Tao, H., Zhou, S., Zeng, Y. 2013. Bio-electro-Fenton system for enhanced estrogens degradation. Bioresour. Technol., 138, 136-140.

Xu, N., Zhou, S., Yuan, Y., Qin, H., Zheng, Y., Shu, C. 2011. Coupling of anodic biooxidation and cathodic bioelectro-Fenton for enhanced swine wastewater treatment. Bioresour. Technol., 102(17), 7777-7783.

Yuan, S.-J., Sheng, G.-P., Li, W.-W., Lin, Z.-Q., Zeng, R.J., Tong, Z.-H., Yu, H.-Q. 2010. Degradation of organic pollutants in a photoelectrocatalytic system enhanced by a microbial fuel cell. Environ. Sci. Technol., 44(14), 5575-5580.

Zhao, Y., Jiangyong, H., Chen, H. 2010. Elimination of estrogen and its estrogenicity by heterogeneous photo-Fenton catalyst $\beta-\mathrm{FeOOH} / \mathrm{resin}$. J. Photochem. Photobiol. A: Chem., 212(2), 94-100.

Zhu, X., Logan, B.E. 2013. Using single-chamber microbial fuel cells as renewable power sources of electro-Fenton reactors for organic pollutant treatment. J. Hazard. Mater., 252, 198-203.

$\mathrm{Zhu}, \mathrm{X} ., \mathrm{Ni}, \mathrm{J}$. 2009a. Simultaneous processes of electricity generation and $p$-nitrophenol degradation in a microbial fuel cell. Electrochemistry Communications, 11(2), 274-277.

$\mathrm{Zhu}, \mathrm{X} ., \mathrm{Ni}, \mathrm{J}$. 2009b. Simultaneous processes of electricity generation and $<\mathrm{i}>\mathrm{p}</ \mathrm{i}>$-nitrophenol degradation in a microbial fuel cell. Electrochemistry Communications, 11(2), 274-277.

Zhuang, L., Zhou, S., Li, Y., Liu, T., Huang, D. 2010a. In situ Fenton-enhanced cathodic reaction for sustainable increased electricity generation in microbial fuel cells. J. Power Sources, 195(5), 1379-1382.

Zhuang, L., Zhou, S., Yuan, Y., Liu, M., Wang, Y. 2010b. A novel bioelectro-Fenton system for coupling anodic COD removal with cathodic dye degradation. Chem. Eng. J., 163(1), 160-163. 
Table 1. Characteristics of medicinal herbs wastewater used

\begin{tabular}{|c|c|c|}
\hline Characteristics & Range value & Average value \pm SD \\
\hline $\mathrm{pH}$ & $11.5-12.3$ & $12.15 \pm 0.61$ \\
\hline Electrical conductivity (EC), $\mu \mathrm{s} \mathrm{cm}^{-1}$ & $1300-1378$ & $1355 \pm 68$ \\
\hline Oil \& grease, $\mathrm{mg} \mathrm{L}^{-1}$ & $462-480$ & $477 \pm 24$ \\
\hline Total COD (TCOD), $\mathrm{mg} \mathrm{L}^{-1}$ & 6094-6212 & $6183 \pm 309$ \\
\hline Soluble COD (SCOD), $\mathrm{mg} \mathrm{L}^{-1}$ & $4398-4476$ & $4425 \pm 221$ \\
\hline $\mathrm{BOD}, \mathrm{mg} \mathrm{L}^{-1}$ & $2207-2313$ & $2250 \pm 112$ \\
\hline Total solids (TS), $\mathrm{mg} \mathrm{L}^{-1}$ & $2260-2431$ & $2333 \pm 117$ \\
\hline Suspended solids (TSS), $\mathrm{mg} \mathrm{L}^{-1}$ & $1383-1498$ & $1423 \pm 71$ \\
\hline Volatile suspende solids (VSS), $\mathrm{mg} \mathrm{L}^{-1}$ & $1145-1280$ & $1211 \pm 61$ \\
\hline TKN, mg L & $17.01-18.76$ & $17.92 \pm 0.90$ \\
\hline Phosphate, $\mathrm{mg} \mathrm{L}^{-1}$ & $0.25-0.36$ & $0.3 \pm 0.015$ \\
\hline Sulfate, $\mathrm{mg} \mathrm{L}^{-1}$ & $36-41$ & $38 \pm 1.9$ \\
\hline Nitrate, $\mathrm{mg} \mathrm{L}^{-1}$ & $1.14-1.31$ & $1.24 \pm 0.06$ \\
\hline Nitrite, $m g L^{-1}$ & $0.14-0.17$ & $0.16 \pm 0.008$ \\
\hline Chloride, $\mathrm{mg} \mathrm{L}^{-1}$ & $3.9-4.5$ & $4.2 \pm 0.21$ \\
\hline
\end{tabular}


Table 2. Comparison of performance of different BEF reactors in power generation, COD removal, Coulombic efficiency and energy conversion efficiency of medicinal herbs wastewater

\begin{tabular}{|c|c|c|c|c|c|c|c|c|c|c|c|c|c|}
\hline \multirow{2}{*}{$\begin{array}{l}\text { Type of BEF reactor, } \\
\text { MLSS/Nafion }\end{array}$} & \multirow{2}{*}{$\begin{array}{l}\text { Amount of } \\
\text { initial iron } \\
\text { salt, } g\end{array}$} & \multirow{2}{*}{$\begin{array}{l}\mathrm{OCV}_{\max } \\
\mathrm{mV}\end{array}$} & \multirow[t]{2}{*}{$I_{\max }, \mathrm{mA} \mathrm{m}^{-2}$} & \multirow{2}{*}{$\begin{array}{l}P_{\max }, \\
\mathrm{mW} \mathrm{m}^{-2}\end{array}$} & \multicolumn{2}{|c|}{ Con., mg L ${ }^{-1}$} & \multirow{2}{*}{$\begin{array}{l}\mathrm{Fe} / \mathrm{H}_{2} \mathrm{O}_{2} \\
\text { molar } \\
\text { ratio }\end{array}$} & \multicolumn{2}{|c|}{ Final $\mathrm{pH}$} & \multicolumn{2}{|c|}{ COD removal, \% } & \multirow[t]{2}{*}{$\epsilon_{\mathrm{cb}}, \%$} & \multirow[t]{2}{*}{$\epsilon_{\mathrm{E},} \%$} \\
\hline & & & & & $\mathrm{H}_{2} \mathrm{O}_{2}$ & $\mathrm{Fe}^{2+}$ & & Anode & Cathode & Anode & Cathode & & \\
\hline 3000/Salt Bridge & 0.9 & 216 & 155.89 & 8.74 & 0.28 & 18.9 & 40.98 & 5.46 & 4.02 & 67.92 & 39.02 & 0.65 & 0.15 \\
\hline $500 / 112$ & 0.9 & 289 & 300.41 & 25.51 & 0.39 & 24 & 37.36 & 6.60 & 4.62 & 51.43 & 57.50 & 0.74 & 0.40 \\
\hline $1000 / 112$ & 0.9 & 342 & 456.80 & 37.64 & 0.47 & 26.5 & 34.23 & 6.50 & 6.06 & 62.84 & 68.80 & 1.65 & 0.69 \\
\hline $1500 / 112$ & 0.9 & 538 & 511.10 & 49.76 & 0.56 & 29 & 31.44 & 4.49 & 7.53 & 70.39 & 78.42 & 3.56 & 1.19 \\
\hline $3000 / 112$ & 0.9 & 600 & 550.21 & 60.43 & 0.62 & 31 & 30.36 & 4.30 & 7.61 & 78.05 & 84.02 & 4.09 & 1.37 \\
\hline $3000 / 115$ & 0.9 & 376 & \begin{tabular}{|l|}
434.83 \\
\end{tabular} & 38.29 & 0.49 & 26.2 & 32.46 & 5.70 & 6.05 & 67.33 & 69.82 & 2.34 & 0.68 \\
\hline $3000 / 112$ & 0.7 & 381 & 420.80 & 38.34 & 0.51 & 27 & 32.14 & 5.42 & 6.10 & 68.37 & 70.54 & 2.59 & 0.67 \\
\hline $3000 / 112$ & 1.1 & 422 & 474.57 & 42.40 & 0.52 & 27.2 & 31.76 & 5.60 & 6.14 & 67.40 & 74.64 & 2.95 & 0.82 \\
\hline
\end{tabular}

${ }^{\mathrm{a}} I_{\max } ;$ Maximum current density, ${ }^{\mathrm{b}} P_{\max } ;$ Maximum power density 


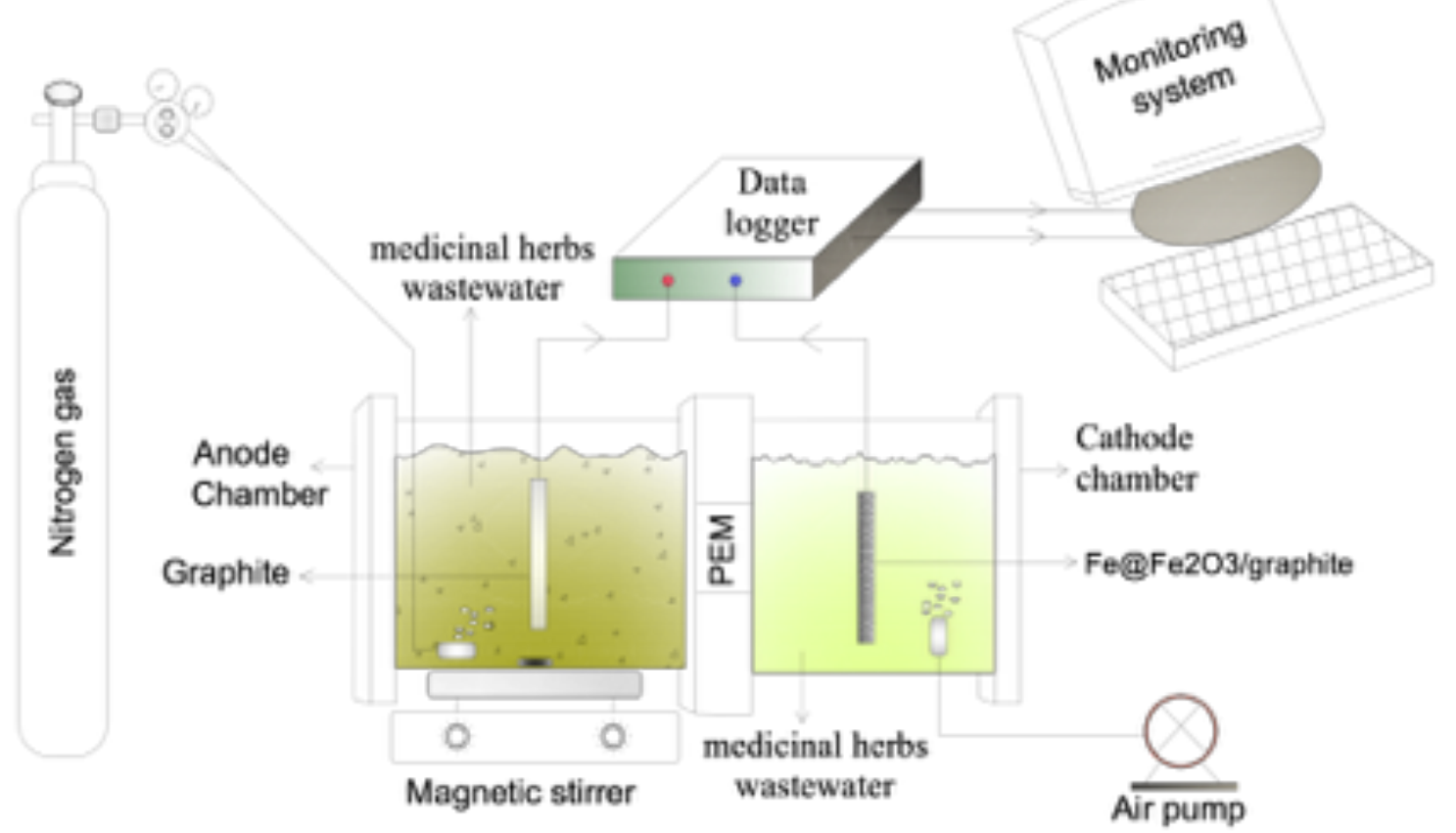

Fig. 1. Schematic diagram of two chamber BEF system in batch mode 


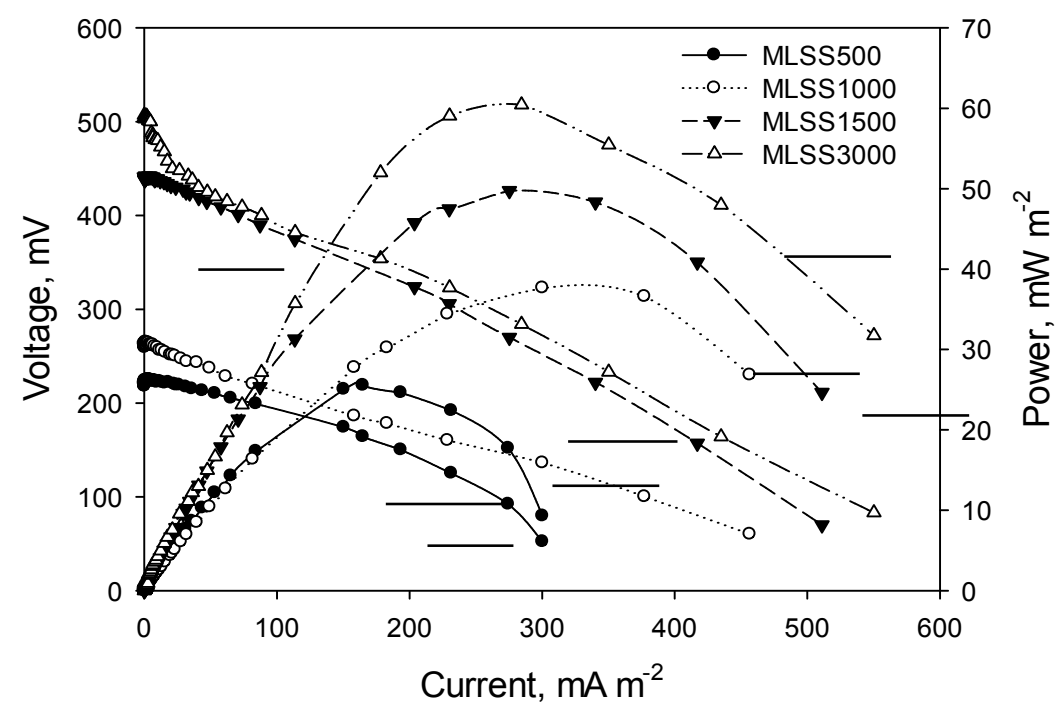

(a)

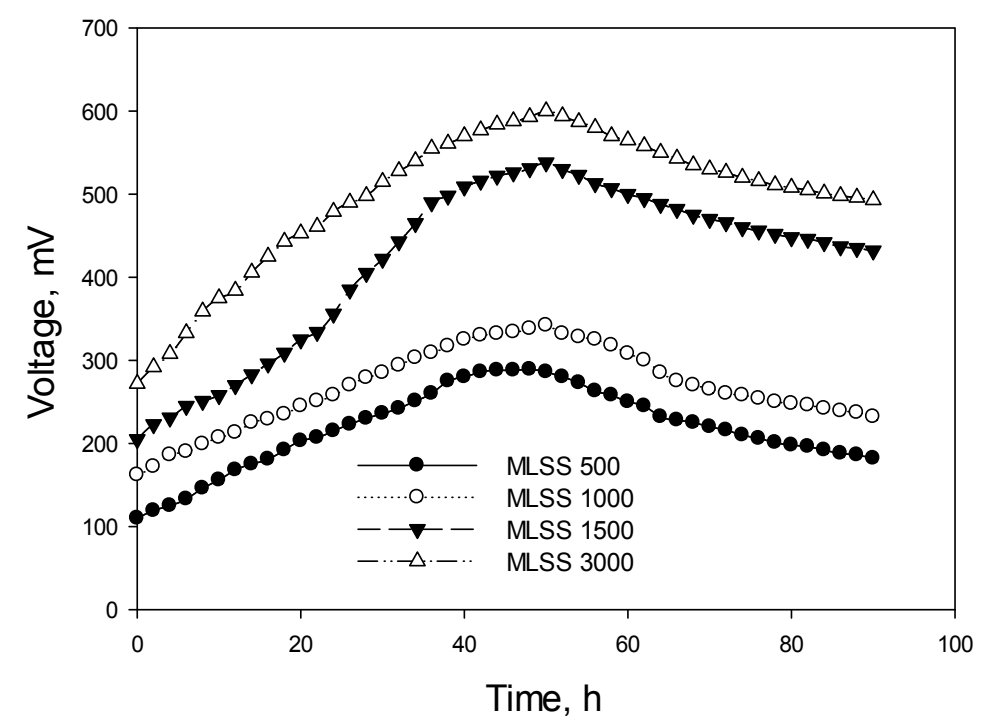

(b)

Fig. 2. Power density as a function of current density (a) and OCV produced (b) in batch BEF systems using medicinal herbs wastewater with different initial MLSS concentrations in the anode chamber and at $\mathrm{pH} 7$, using Nafion 112 membrane and $0.9 \mathrm{~g}$ of the initial amount of $\mathrm{FeCl}_{3}-6 \mathrm{H}_{2} \mathrm{O}$ constructed $\mathrm{Fe} @ \mathrm{Fe}_{2} \mathrm{O}_{3} /$ graphite composite cathode 


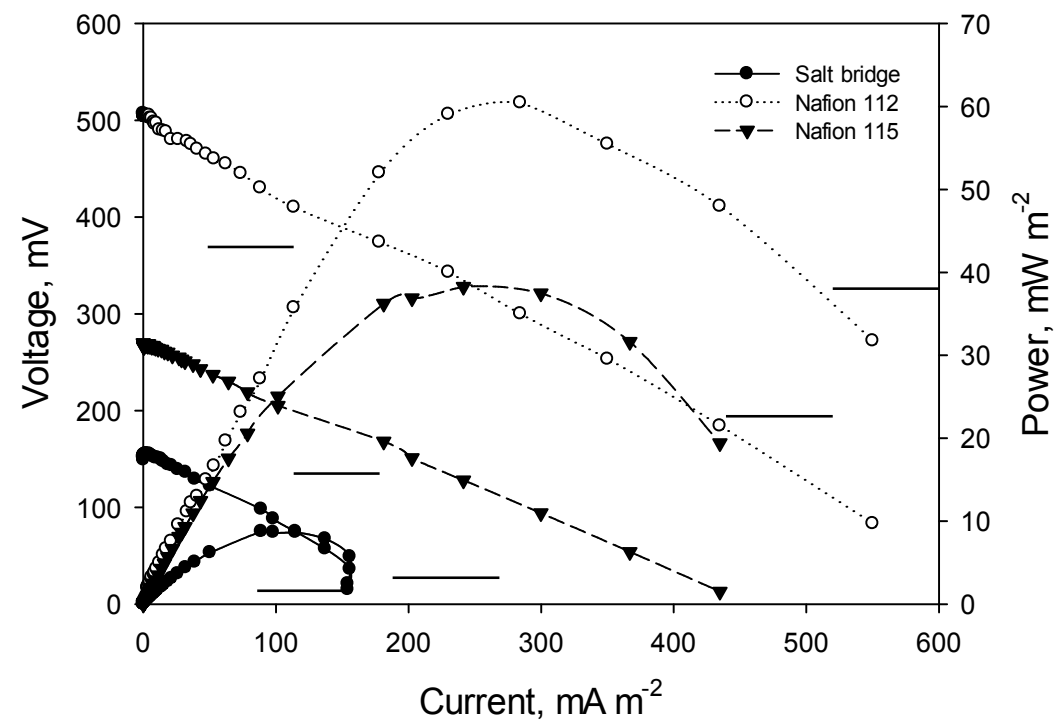

(a)

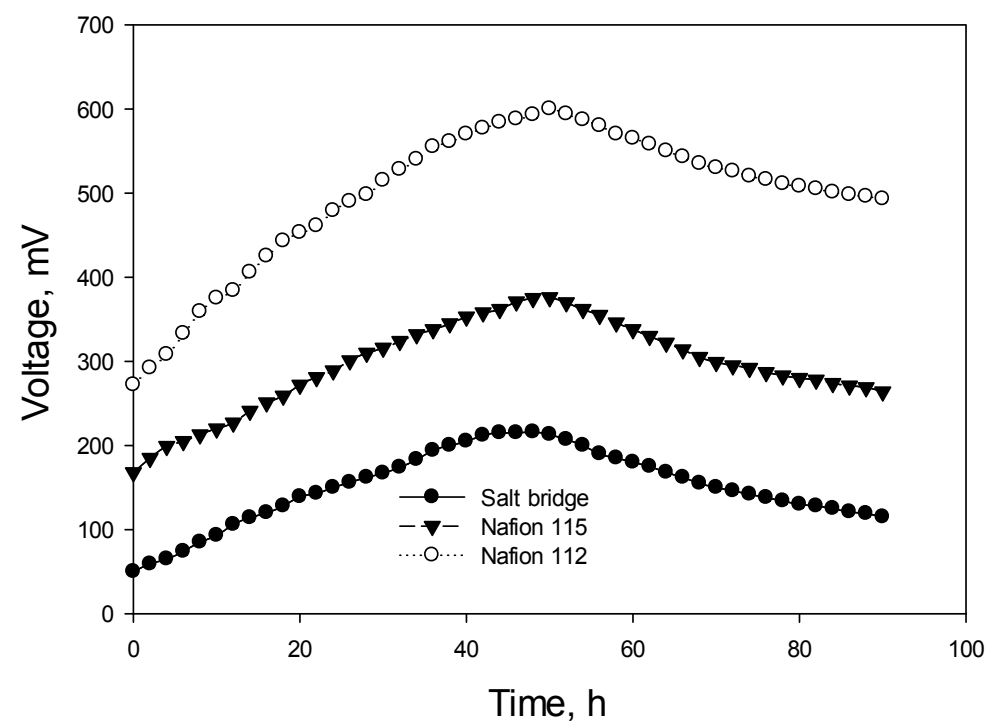

(b)

Fig. 3. Polarization curves and (a) time-voltage curves (b) of BEF reactors using medicinal herbs wastewater using salt bridge and two types of Nafion 112, 115 membranes at a constant initial MLSS concentration of $3000 \mathrm{mg} \mathrm{L}^{-1}$ at $\mathrm{pH} 7$ in the anode chamber, using Nafion 112 membrane and $0.9 \mathrm{~g}$ of the initial amount of $\mathrm{FeCl}_{3}-6 \mathrm{H}_{2} \mathrm{O}$ constructed $\mathrm{Fe} @ \mathrm{Fe}_{2} \mathrm{O}_{3} /$ graphite composite cathode at $\mathrm{pH} 3$ in the cathode chamber 


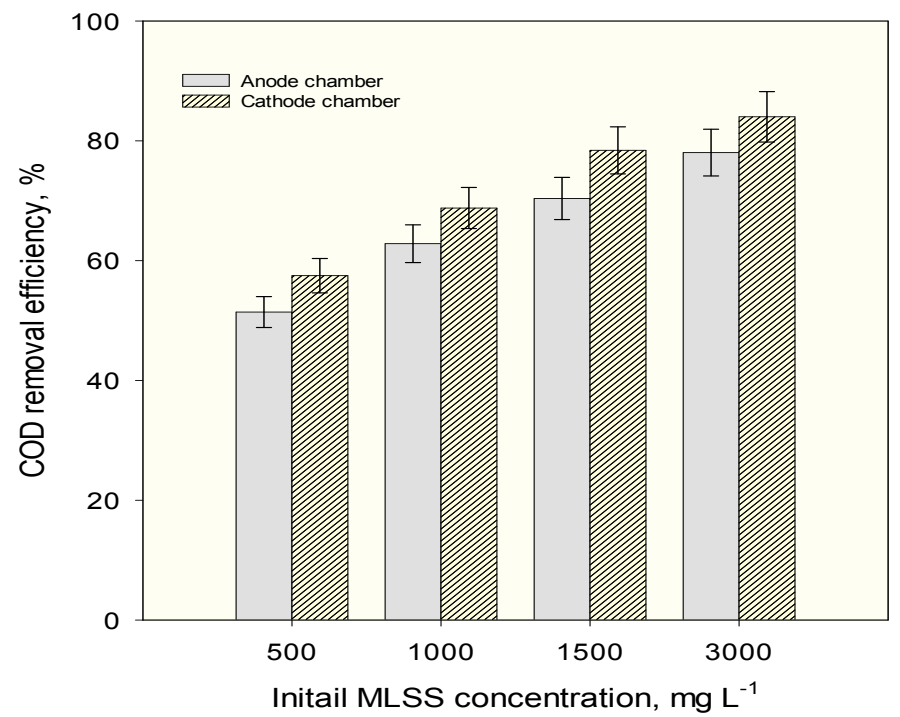

Fig. 4. COD removal efficiency (\%) of medicinal herbs wastewater in the anodic and cathodic chamber of BEF reactors with different initial MLSS concentration and $\mathrm{pH} 7$

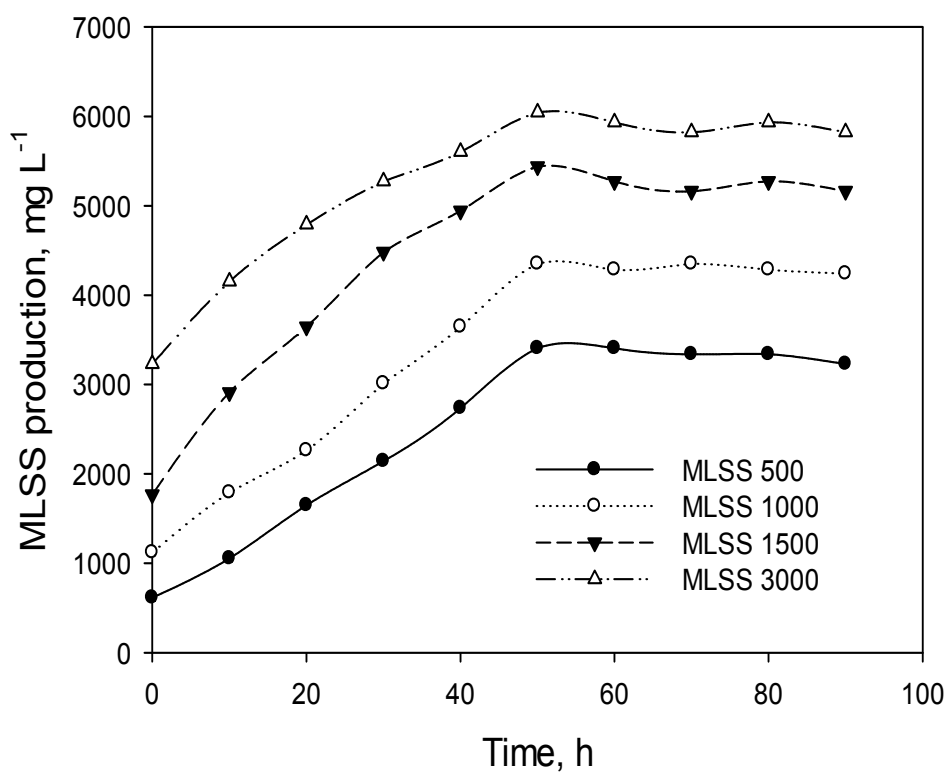

Fig. 5. MLSS production with different initial MLSS in the anode chamber of BEF reactors 


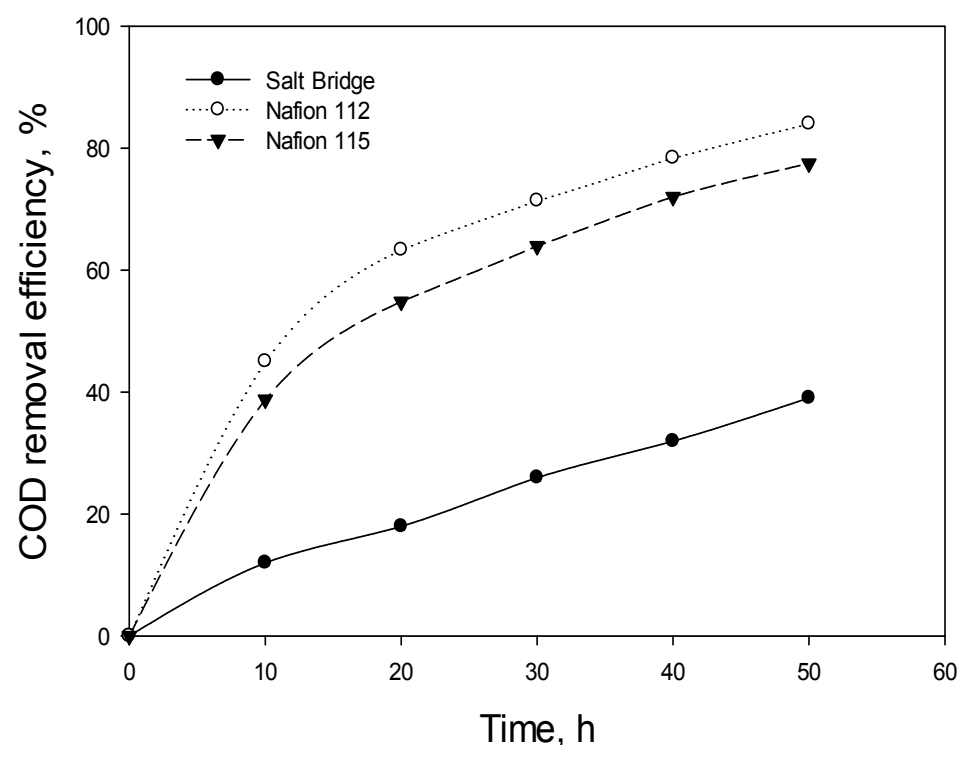

Fig. 6. The effect of Nafion membrane on the COD removal of medicinal herbs wastewater in the cathodic chamber with MLSS $3000 \mathrm{mg} \mathrm{L}^{-1}$ and $\mathrm{pH} 7$ in the anode chamber, $0.9 \mathrm{~g}$ of the initial amount of $\mathrm{FeCl}_{3}-6 \mathrm{H}_{2} \mathrm{O}$ constructed $\mathrm{Fe} @ \mathrm{Fe}_{2} \mathrm{O}_{3} /$ graphite composite cathode at $\mathrm{pH} 3$ in the cathode chamber 


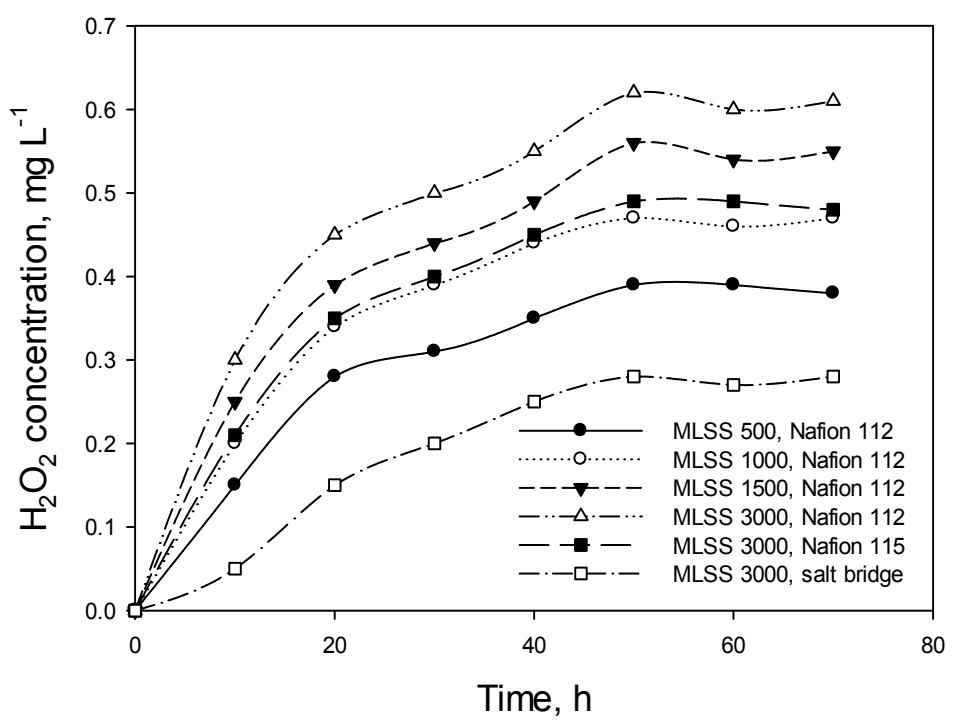

(a)

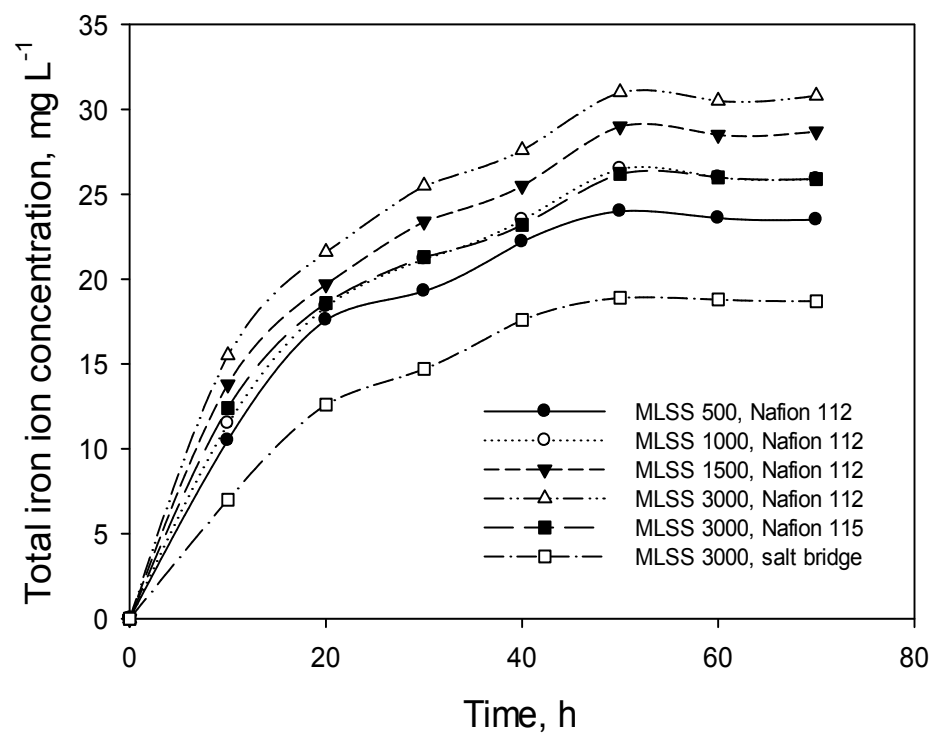

(b)

Fig. 7. Concentration of $\mathrm{H}_{2} \mathrm{O}_{2}$ (a) and total iron ion (b) as a function of time in the cathode chamber bubbled with air at a rate of $300 \mathrm{~mL} \mathrm{~min}^{-1}$ and with different initial MLSS 


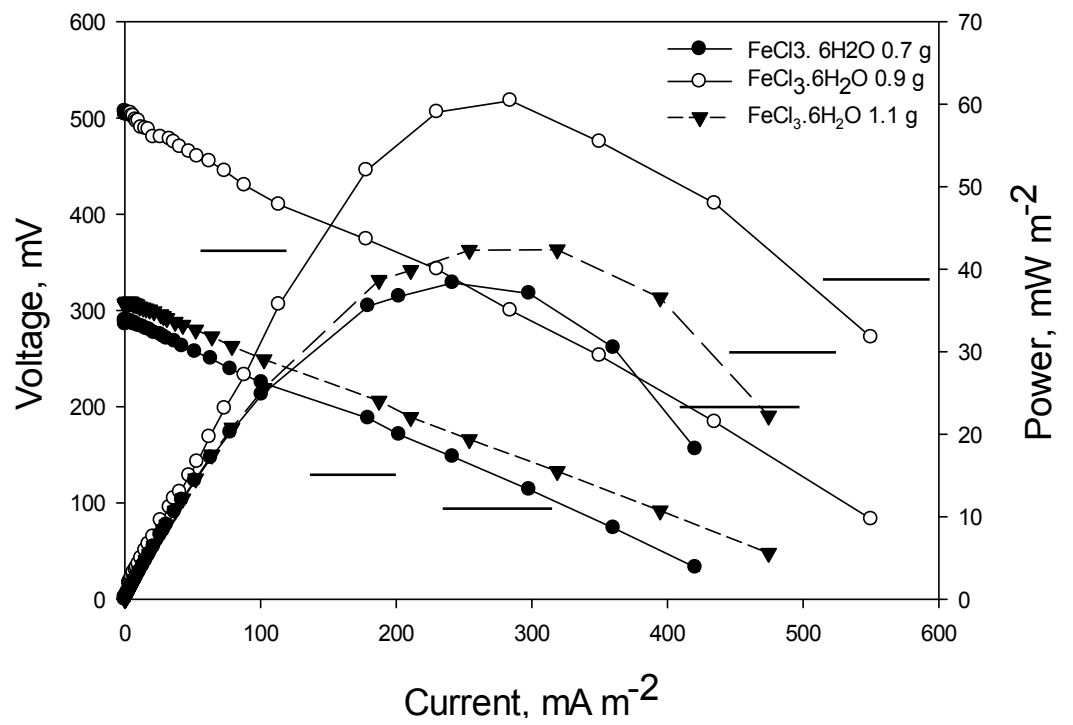

(a)

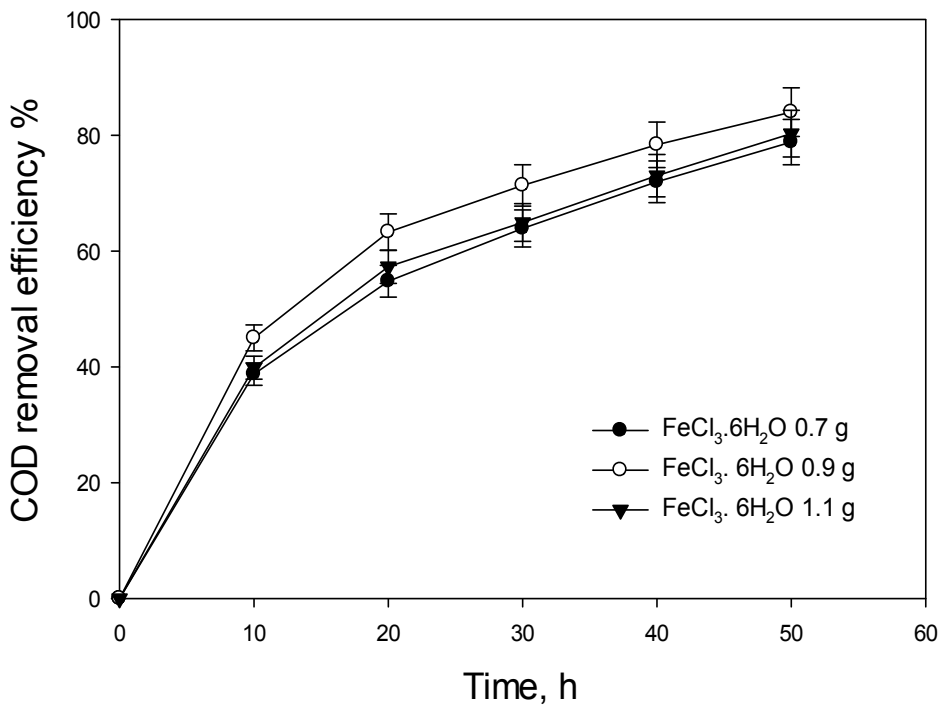

(b)

Fig. 8. Polarization curves (a) and COD removal efficiency (b) of three BEF reactors equipped with different amount of $\mathrm{FeCl}_{3}-6 \mathrm{H}_{2} \mathrm{O}$ with MLSS $3000 \mathrm{mg} \mathrm{L}^{-1}$ and at $\mathrm{pH} 7$ in the anode chamber using Nafion 112 (average value \pm standard deviation) 


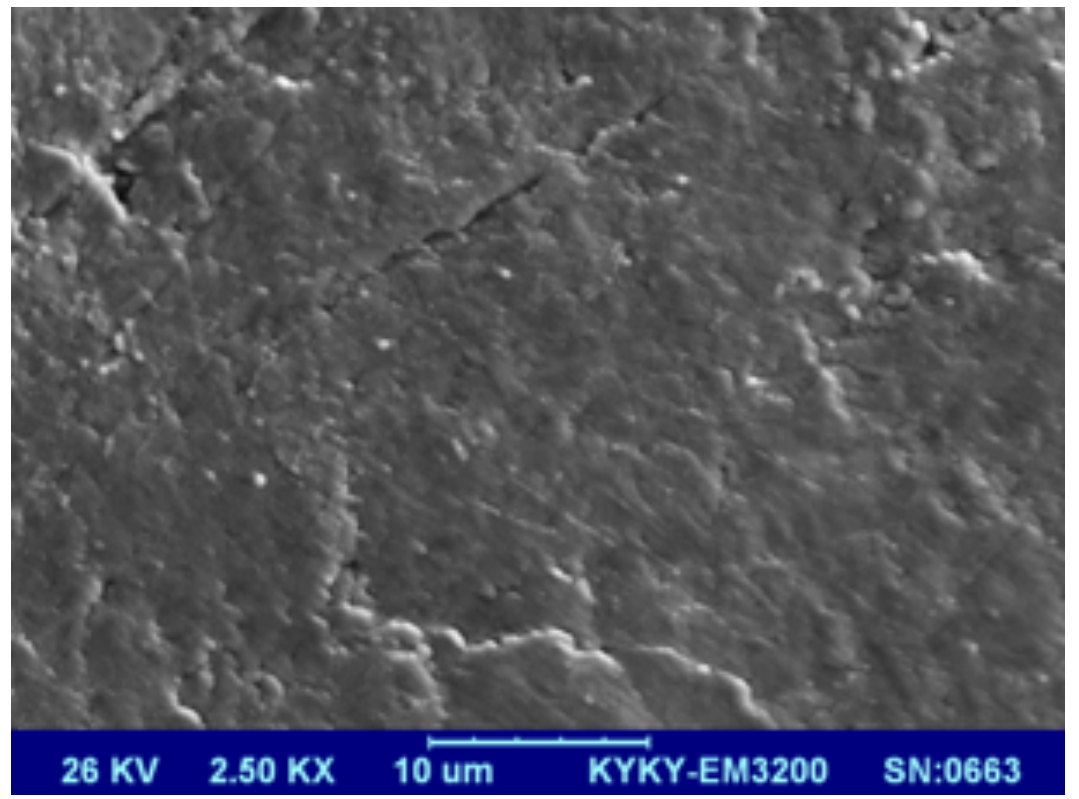

(a)

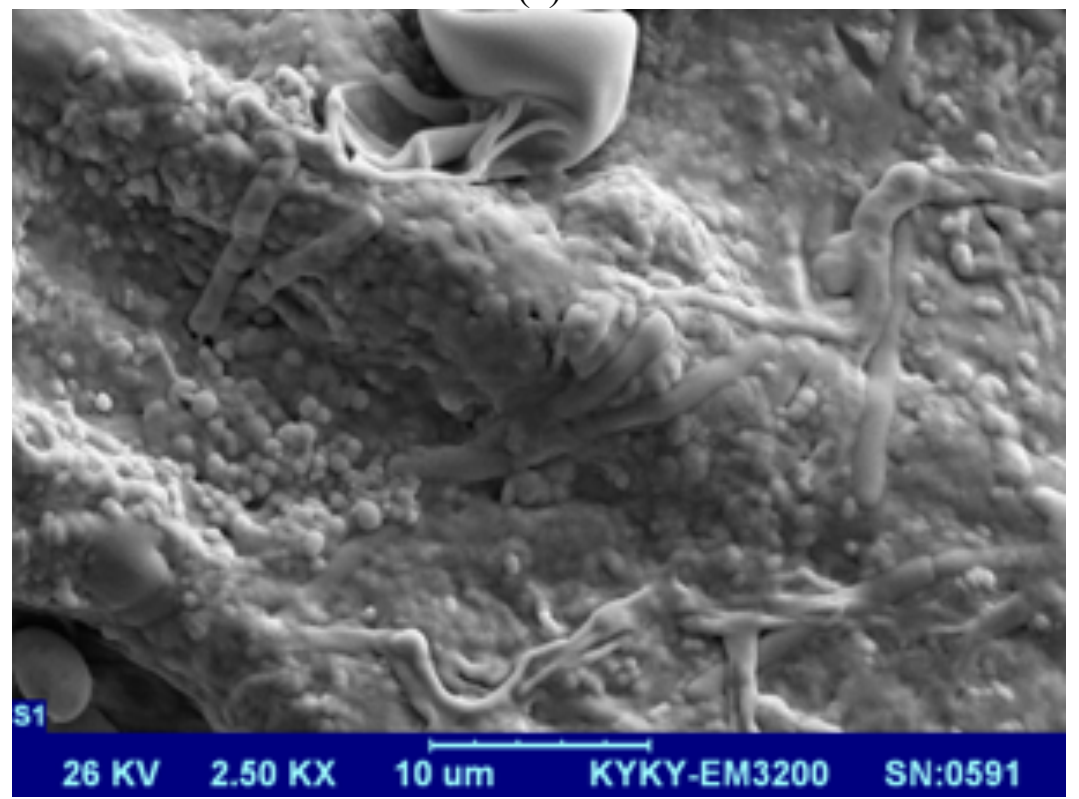

(b)

Fig. 9. SEM images from the outer surface of anode electrode before (a) and after (b) using in anode compartment 